Contract AT(30-1)-4161

\title{
Development of a
}

High Voltage Heat Pipe

Thermonic Module

\section{Final Technical Report}

THIS DOCUMENT CONFIBMED AS UNCLASSIFIED

DIVISION OF CLASSIFICATION

BY CH Kahal amb

Period of Performance

October 1, 1969 through June 30, 1971

\section{R:3709}

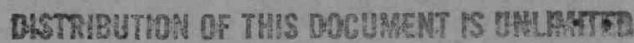

Prepared for

U.S. ATOMIC ENERGY COMMISSION 


\section{DISCLAIMER}

This report was prepared as an account of work sponsored by an agency of the United States Government. Neither the United States Government nor any agency Thereof, nor any of their employees, makes any warranty, express or implied, or assumes any legal liability or responsibility for the accuracy, completeness, or usefulness of any information, apparatus, product, or process disclosed, or represents that its use would not infringe privately owned rights. Reference herein to any specific commercial product, process, or service by trade name, trademark, manufacturer, or otherwise does not necessarily constitute or imply its endorsement, recommendation, or favoring by the United States Government or any agency thereof. The views and opinions of authors expressed herein do not necessarily state or reflect those of the United States Government or any agency thereof. 


\section{DISCLAIMER}

Portions of this document may be illegible in electronic image products. Images are produced from the best available original document. 
DEVELOPMENT OF A HIGH VOLTAGE HEAT PIPE THERMIONIC MODULE

FINAL TECHNICAL REPORT

Author - R.W. Longsderff

Period of Performance

October I, 1969 through June 30, 1971

Prepared for

U. S. ATOMIC ENERGY COMMISSION

New York Operations Office

New York, New York

Prepared by

RCA CORPORATION

Electronic Components

Industrial Tube Division

Lancaster, Pennsylvania

\section{NOTICE}

This report was prepared as an account of work nsored by the United States Government. Neither United States nor the United States Atomic Energy fommission, nor any of their employees, nor any of their contractors, subcontractors, or their employees, makes any warranty, express or implied, or assumes any legal liability or responsibility for the accuracy, completeness or usefulness of any information, apparatus, product or process disclosed, or represents that its use would not infringe privately owned rights.
July 1971 


\section{NOTICE}

This report was prepared as an account of work sponsored by the United States Government. Neither the United States nor the United States Atomic Energy Commission, nor any of their employees, makes any warranty, express or implied, or assumes any legal liability or responsibility for the accurace, completeness or usefulness of any information, apparatus, product or process disclosed, or represents that its use would not infringe privatly owned rights.

\section{AVAILABILITY NOTICE}

Printed in the United States of America Available from

National Technical Information Services Springfield, Virginia 22151

Price: Printed Copy $\$ \underline{3.00}$; Microfiche $\$ 0.65$ 
FOREWORD

This report was prepared by RCA, Lancaster, Pennsylvania, under U. S. Atomic Energy Commission Contract AT(30-1)-416I entitled "Development of a High Voltage Heat Pipe Thermionic Module." Mr. Lester Price served as Technical Director of the program for the U. S. Atomic Energy Commission, Space Nuclear Systems Division, Germantown, Maryland.

This Final Technical Report covers the work performed during the period from October 1, 1969 through June 30, 1971. The work described herein represents the efforts of the Special Power Devices Engineering Department. Mr. R. W. Longsderff provided technical direction for the program, directing a group of technical personnel in performance of the actual program of work. 
TABLE OF CONTENTS

Section

Title

Page

I

Introduction

1

II

Program Accomplishments

2

I. Task I

2

A. Heat Pipe Development

2

B. Module Design and Fabrication

6

C. Module Assembly

22

II. Task II - Advanced High Voltage Module Technology

A. Tri-Layer Technology

B. Arc Suppression Coatings

40

Conclusions and Recommendations

52

Appendix A Converter Power Loss Analysis 


\section{LIST OF ILLUSTRATIONS}

Figure

Title

Page

1

Photograph of Basic High Voltage Module Design Concept

High Voltage Module Heat Pipe

5

3

Basic Module Design

7

4

Converter Cross-Sectional Dimensions

8

5

Schematic Diagram of Vacuum Coating Technique

10

6

Cross-Sectional Drawing of Vacuum Coating

12

7

Cross-Sectional Drawing of Emitter/Collector

Tri-Layer Electrode Assembly

Cross-Sectional Drawing of Electron Beam Welding

Fixture for Electrode Sub-Assembly Fabrication

Emitter Lead Sub-Assembly

Collector Lead Sub-Assembly

Emitter/Collector Tri-Layer Sub Assemblies

Interelectrode Lead Slotting Details

Interelectrode Slotting Fixture

End Closure and Power Lead Sub-Assembly

Exhaust Tubulation Sub-Assembly

Scanning Electron Microscope Photograph of Aluminum/Yttria Arc-Suppression Coating

Lower Diaphragm and Collector Power Lead 
Molybdenum Sample A - Prior to Coating with $\mathrm{Al}_{2} \mathrm{O}_{3}$

Molybdenum Sample A - After Coating with 25,000 \& of $\mathrm{Al}_{2} \mathrm{O}_{3}$

Molybdenum Sample B - Prior to Coating with $\mathrm{Al}_{2} \mathrm{O}_{3}$

45

29

Molybdenum Sample B - After Coating with 25,000 \& of $\mathrm{Al}_{2} \mathrm{O}_{3}$

Molybdenum Sample C - Prior to Coating with $\mathrm{Al}_{2} \mathrm{O}_{3}$

Molybdenum Sample C - After Coating with 25,000 \& of $\mathrm{Al}_{2} \mathrm{O}_{3}$

Molybdenum Sample D - After Coating with 25,000 \& of $\mathrm{Al}_{2} \mathrm{O}_{3}$

Photograph of Tri-Layer End-Area Coated with $25,000 \AA$ of $\mathrm{Al}_{2} \mathrm{O}_{3}$ 


\section{LIST OF TABLES}

Table

I
Title

Module Flow Chart
Page

26 


\section{DEVELOPMENT OF A HIGH VOLTAGE \\ HEAT PIPE THERMIONIC MODULE \\ Contract $\mathrm{AT}(30-1)-4161$}

\section{SECTION I}

INTRODUCTION

This report describes RCA's efforts to design, fabricate and test a 5 volt, 10 diode, heat pipe thermionic module. The program was originally organized into three major tasks as follows: Task I - Heat Pipe Thermionic Module Development; Task II - Advanced High Voltage Module Technology; and Task III Development of a 28 volt Thermionic Module. Due to a reduction in overall program effort, Task III was eliminated and efforts were concentrated on Task I.

The basic module design was centered about the design concept developed under Contract AT(30-1)-3979 (see Final Technical Report NYO-3979-3, dated September 1969). This concept consists of individual thermionic diode assemblies mounted on a Common heat pipe and internally series connected by a flexible high temperature lead. The primary objective of Task I was to design, fabricate and test a 5 volt, 10 diode, heat pipe thermionic module.

The primary objectives of Task II were to improve the tri-layer technology necessary for module use and to improve the insulation coatings required for arc-suppression in module applications. 


\section{PROGRAM ACCOMPLISHMENTS}

\section{Task I - Development of a Five Volt Module}

The major emphasis of work for this task was directed to the design and fabrication of a five volt, 10 diode module employing the basic concept developed under Contract $\operatorname{AT}(30-1)-4161$. This basic concept is shown in Figure 1. This effort included work in the areas of heat pipe design and fabrication, electrode fabrication, auxilliary sub-assembly fabrication and module assembly.

\section{A. Heat Pipe Development}

A heat pipe design was established based on the 5 volt, 10 converter module design discussed in later paragraphs of this report. Based on this design (see Appendix "A") a total power requirement of 2850 watts is required of the total system. This was assuming moderate evaporator surface shielding (approximately 5 wraps of 0.001 inch thick dimpled molybdenum foil) and the losses summarized in Appendix "A". The heat pipe dimensions were also dictated by the module design since emitter area and emitter/collector diameters are critical to the overall system efficiency.

A computer analysis was conducted based on these requirements. The results indicated that a heat pipe with dimensions 0.850 inch 0. D. $x$ 0.750 inch I.D. $x 16.75$ inches long ( 7 inch condenser, 9.75 inch evaporator) could transfer more than 7500 watts, using 3 wraps of $60 \mathrm{x}$ 60 mesh molybdenum screen as the wick and operating in a $90^{\circ}$ gravity 


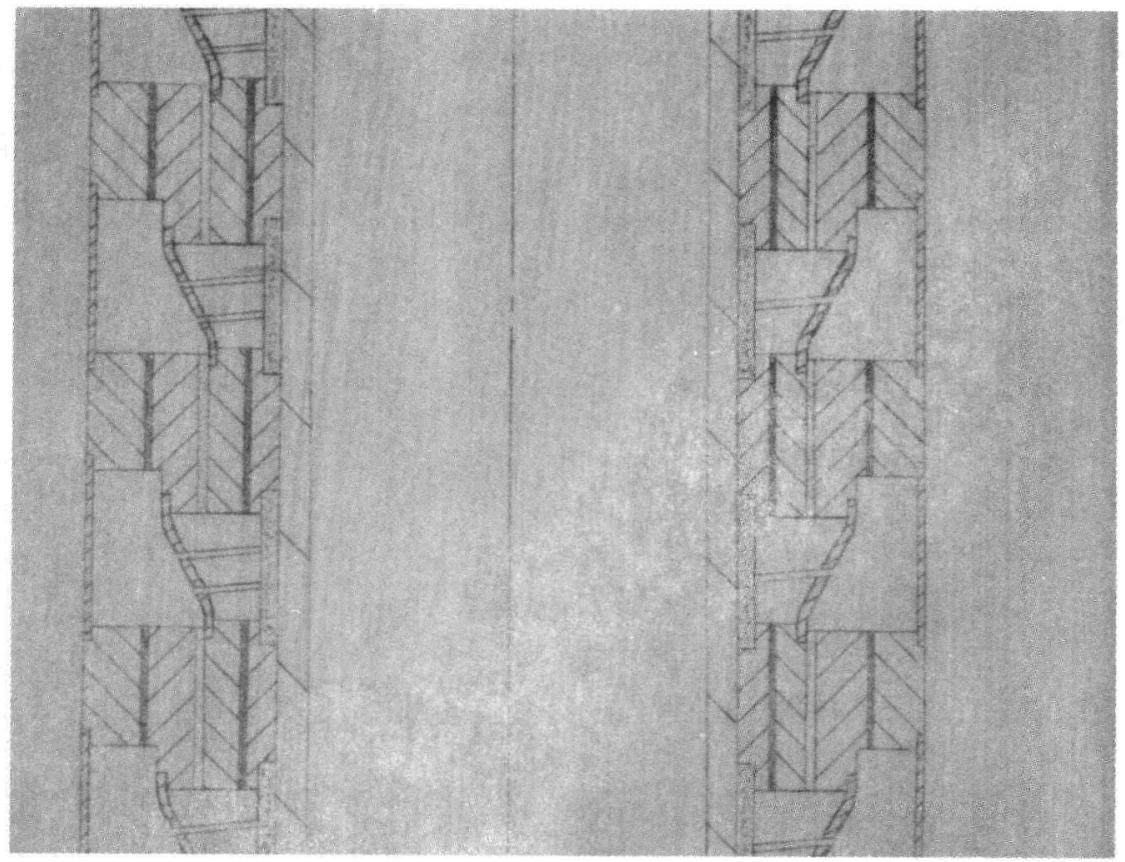

FIGURE 1 PHOTOGRAPH OF BASIC HIGH VOLTAGE MODULE DESIGN CONCEPT 
aiding orientation. The same design operating in a $0^{\circ}$ gravity orientation was capable of transferring more than 3500 watts. The design was chosen for fabrication. A cross-sectional drawing of the design is shown in Figure 2.

The heat pipe was constructed in two pieces and electron beam welded in the condenser area just outside the power lead. This procedure was necessary from a machining point of view.

The heat pipe evaporator section length was calculated, using a computer program to determine the length/cross-sectional area ratio necessary to minimize the magnetic effects due to the high current (2200 amperes) resulting from directly heating the heat pipe. Different methods of heating could result in a shorter evaporator section.

The power leads employed were fabricated from vacuum-arc-cast molybdenum. These leads were designed to clamp onto the heat pipe O.D. surface using molybdenum threaded rod and nuts (1/4-20 thread). These leads also served as mounting clamps for support of the heat pipe during processing and testing.

Following fabrication, the heat pipe was loaded with 8.5 grams of lithium and processed to a temperature of $1600^{\circ} \mathrm{C}$. The unit was then sealed and recycled to insure proper closure. The closure was completed using a molybdenum pin and orifice. 


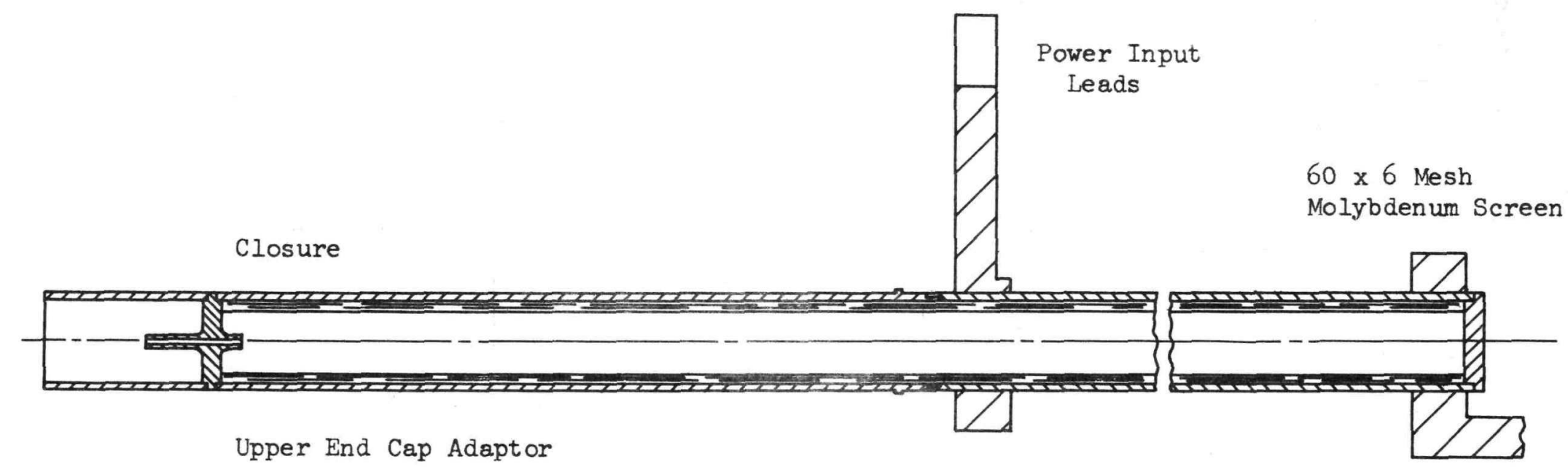

Electron Beam Weld

FIGURE 2 - High Voltage Module Heat Pipe 
Following processing, the heat pipe was set-up for testing.

Temperature measurements were made, using an optical pyrometer, and thermal loading was accomplished by a clamp-on radiation lead. The measurements were taken with a maximum total heat transfer of 4000 watts. At this power level, the maximum temperature gradient measured between evaporator and condenser was $35^{\circ} \mathrm{C}$ at a heat pipe temperature of $1500^{\circ} \mathrm{C}$. These measurements were made with the heat pipe in a horizontal position ( $0^{\circ}$ gravity).

Following test, the heat pipe was set aside to await assembly of the module components.

\section{B. Module Design and Fabrication}

A module design incorporating the basic module concept was established. This design was co-ordinated with the heat pipe design to insure adequate power capability versus diameter dimensions chosen. The design is shown in Figure 3.

1. Design

A design based on heat pipe dimensions of 0.860 inch $0 . D$. and an emitter length of 0.245 inch resulted in an emitter area of $5.5 \mathrm{~cm}^{2}$ for each converter section. A thermal analysis of the system was conducted using the respective dimensions shown in Figure 4. The complete analysis is listed in Appendix A. This analysis was conducted assuming an emitter temperature of $1450^{\circ} \mathrm{C}$, a power density of 3.6 watts $/ \mathrm{cm}^{2}$, and a conversion efficiency of 10 percent. Using these parameters, it was calculated that the emitter tri-layer would have a temperature loss of $15.72^{\circ} \mathrm{C}$. This 


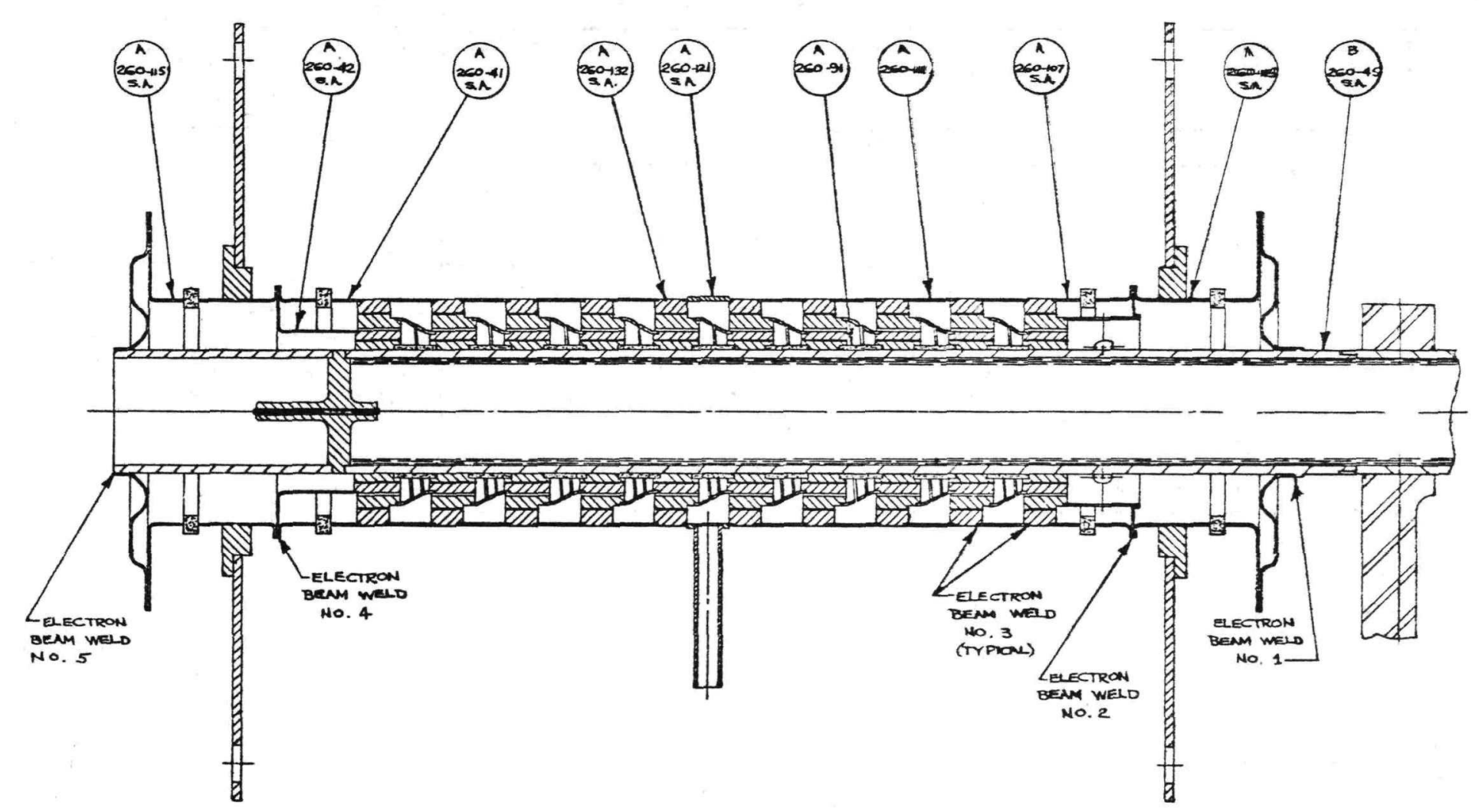

FIGURE 3 - Basic Module Design 
Respective Radii

$\begin{array}{ll}A=0.430 \text { in., } & 1.092 \mathrm{~cm} \\ \mathrm{~B}=0.490 & , 1.245 \\ \mathrm{C}=0.495 & , 1.257 \\ \mathrm{D}=0.570 & , 1.448 \\ \mathrm{E}=0.575 & , 1.460 \\ \mathrm{~F}=0.670 & , 1.702 \\ \mathrm{G}=0.675 & , 1.715 \\ \mathrm{H}=0.780 & , 1.981 \\ \mathrm{~J}=0.517 & , 1.313 \\ \mathrm{~K}=0.320 & , 0.813 \\ \mathrm{~L}=0.197 & , 0.50\end{array}$

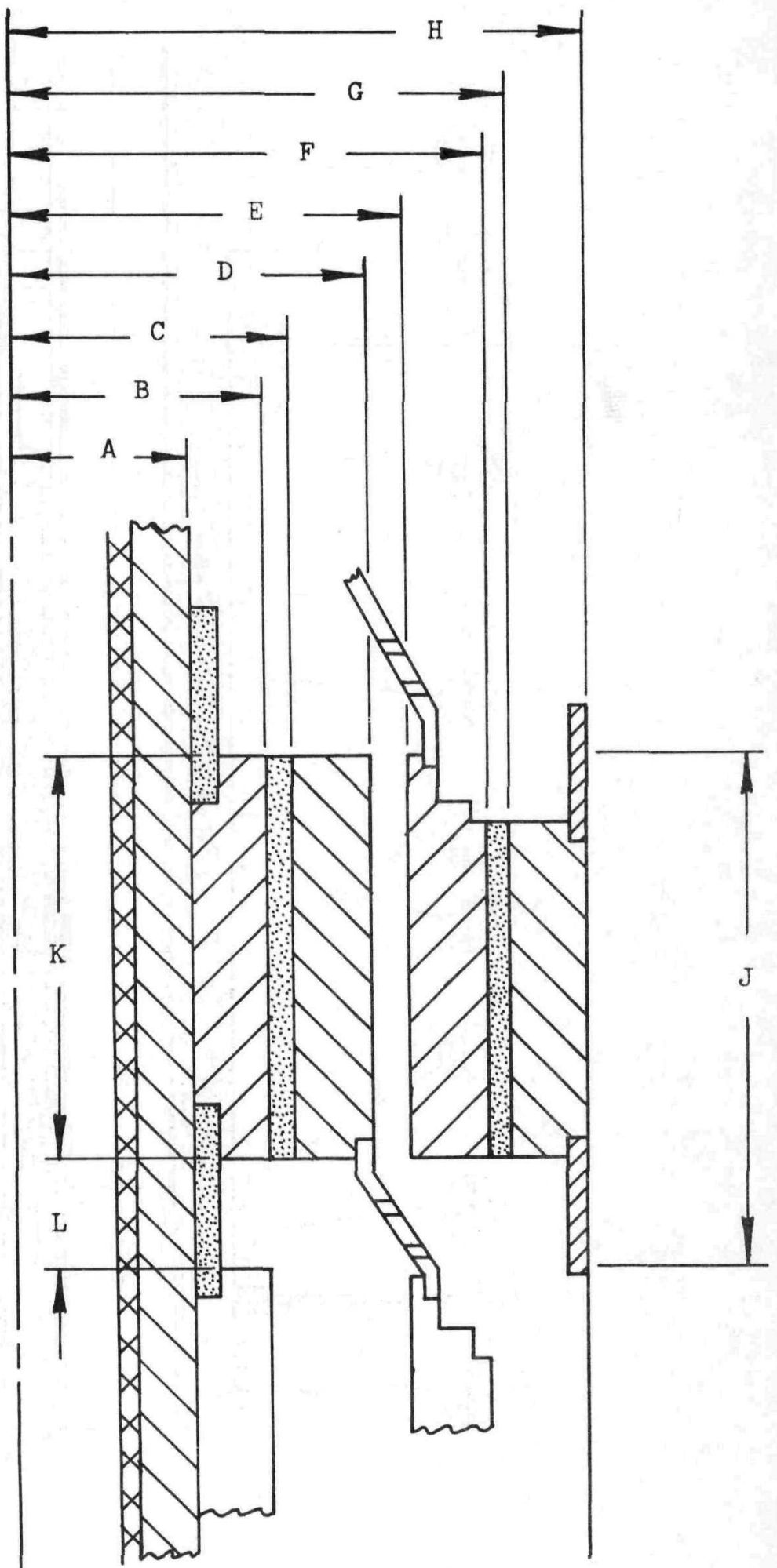

FIGURE 4 - Converter

Cross-Sectional Dimensions 
compares quite well with the values measured during tri-layer evaluation studies. This value plus the heat pipe losses (wick and wall) show a total temperature loss from inside the heat pipe to the emitter surface of $26.5^{\circ} \mathrm{C}$. Thus the heat pipe must be operated at approximately $1475^{\circ} \mathrm{C}$ vapor temperature to achieve the $1450^{\circ} \mathrm{C}$ emitter temperature. These values are true only if a perfect thermal bond is achieved between the emitter tri-layer assembly and the heat pipe outer wall. Therefore, a more practical heat pipe temperature would be $1500^{\circ} \mathrm{C}$. This value is within the design of the heat pipe.

This analysis was continued to determine the thermal loss for each converter device and the total gross power required for the overall module system. A summation of these losses showed that the total power required for each converter was 218 watts. Summarizing the remaining system losses, i.e., end caps, power leads, etc., the total system power required is 2833 watts. This power requirement was used for the heat pipe design analysis discussed previously.

2. Electro이 Fabrication

Fabrication of the emitter/collector tri-layer assemblies was conducted by the technique established under Contract $\operatorname{AT}(30-1)-3979$. Vacuum arc cast molybdenum (Climax-Climelt) was employed in all electrode fabrication. The casting technique employed was also the technique developed under Contract AT(30-1)-3979. A schematic diagram of this technique is shown in Figure 5 and a cross-sectional 


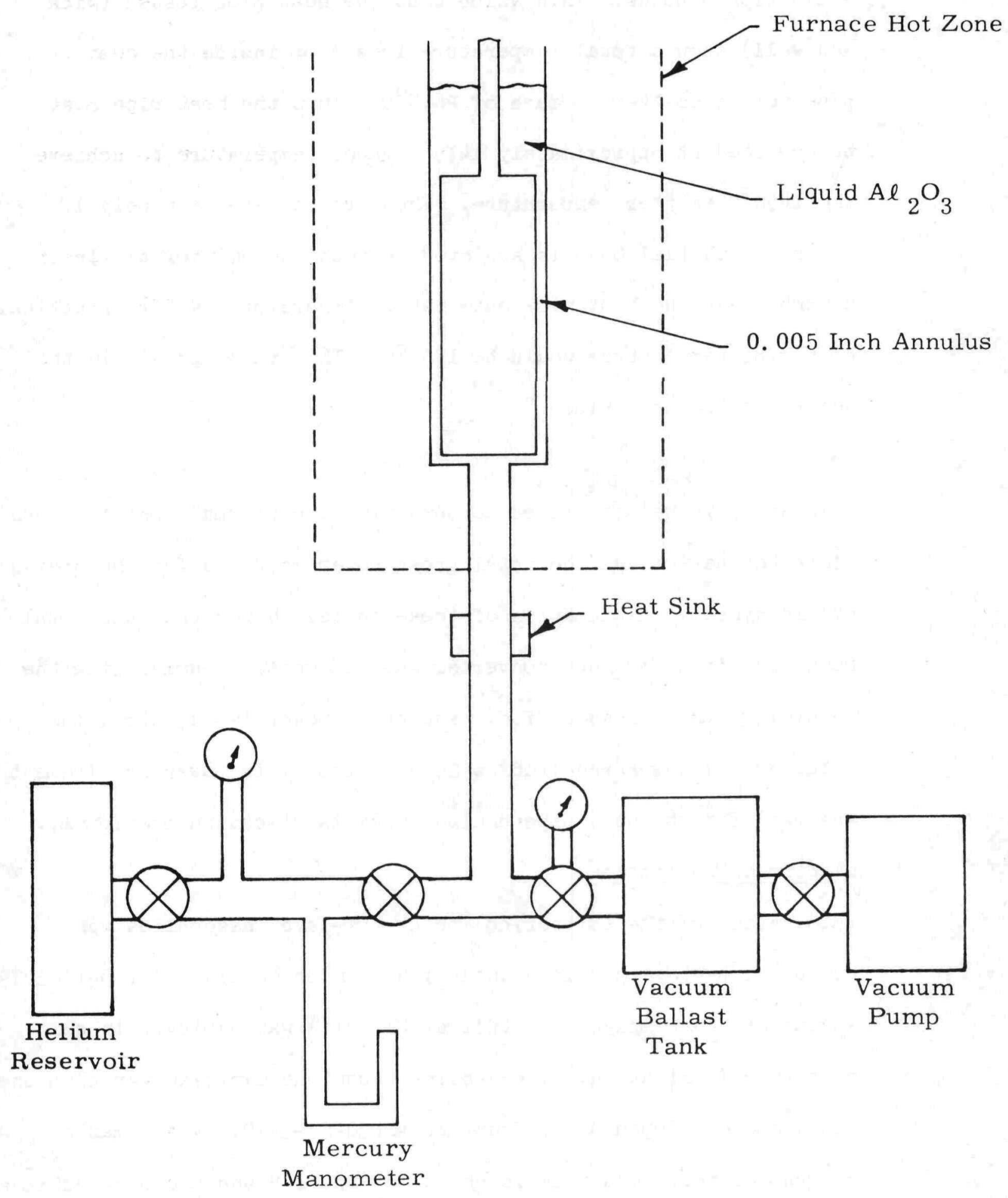

FIGURE 5 SCHEMATIC DIAGRAM OF VACUUM CASTING TECHNIQUE 
drawing of the casting is shown in Figure 6. The casting assembly was machined using facilities employed strictly for the machining of molybdenum, to reduce the change of metallic contaminants. A special recirculating coolant system using special non-sulfur coolant was employed with the machining facility. All parts were cleaned and vacuum fired prior to assembly for casting. All casting jointures were made by an electron beam welding technique. Following casting, sections were cut to proper length for machining. This cutting was accomplished using an Allison No. GCl20 abrasive wheel to prevent chipping and pull-out of the alumina tri-layer, and to reduce the amount of metal "smear-over" in the alumina end-area.

Following completion of machining the respective emitter and collector assemblies were electron beam welded to a non-slotted interconnection lead as shown in Figures 7 and 8 . Two special assemblies (one each end) were required for connections of the external emitter lead at one end and the external collector lead at the other end. These assemblies are shown in Figures 9 and 10, respectively. A photograph of the completed emitter/collector assemblies is shown in Figure 1l. Following electron beam welding, the assemblies were set up for slotting of the inter-connecting lead. 


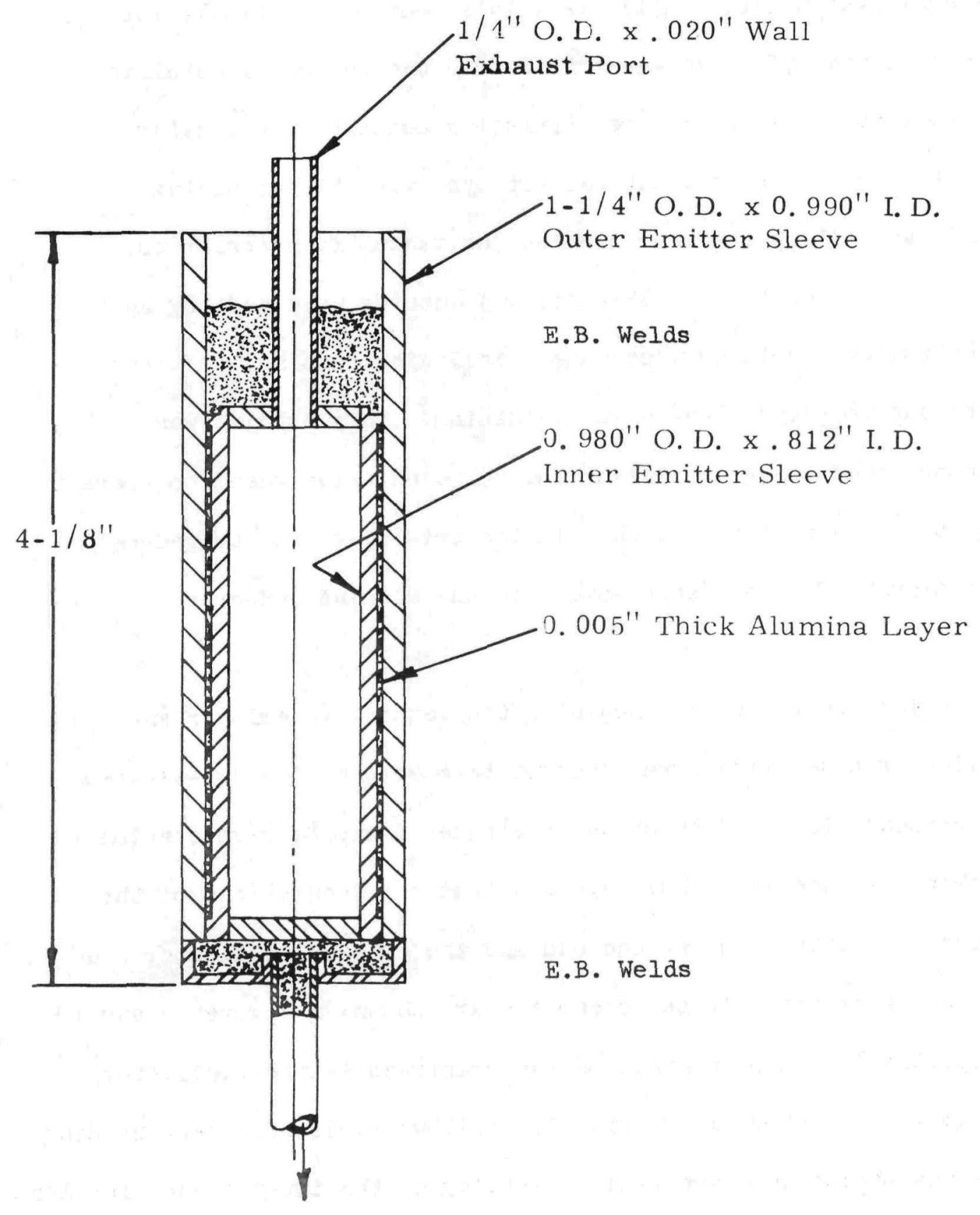

FIGURE 6 CROSS-SECTIONAL DRAWING OF VACUUM CASTING 


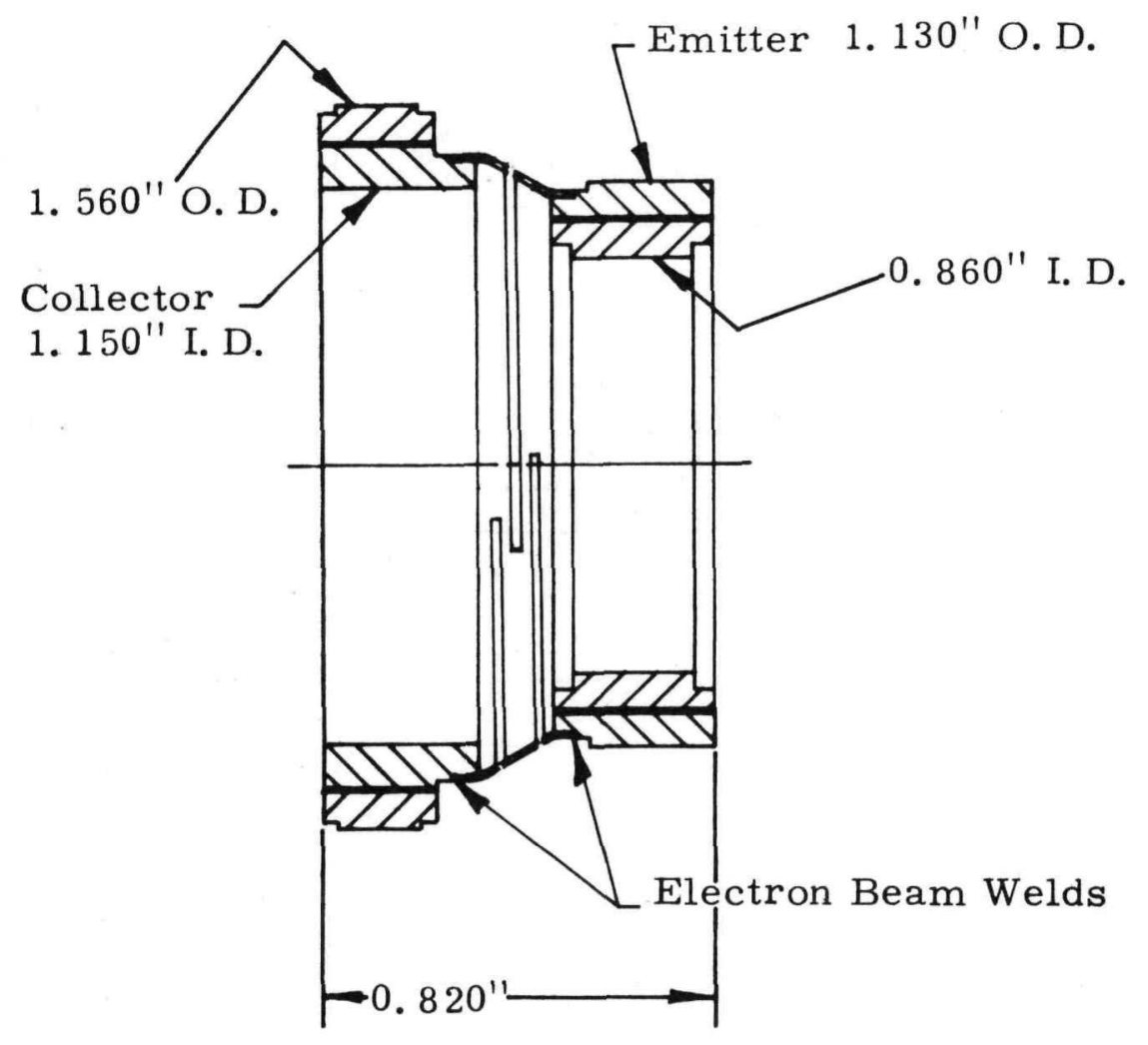

FIGURE 7 CROSS-SECTIONAL DRAWING OF EMITTER/COLLECTOR TRI-LAYER ELECTRODE ASSEMBLY 


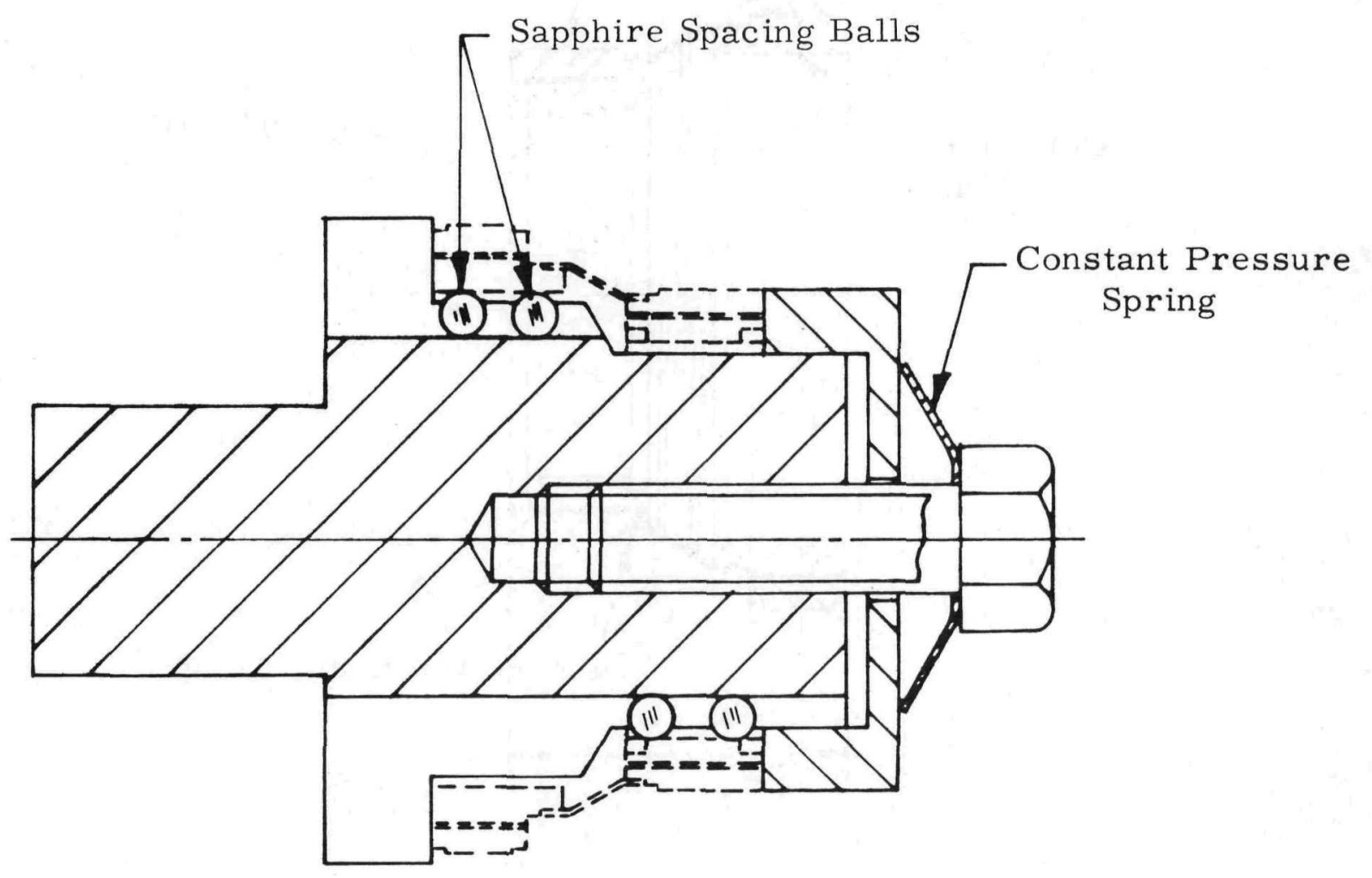

FIGURE 8 CROSS-SECTIONAL DRAWING OF ELECTRON BEAM WELDING FIXTURE FOR ELECTRODE SUB-ASSEMBLY FABRICATION 


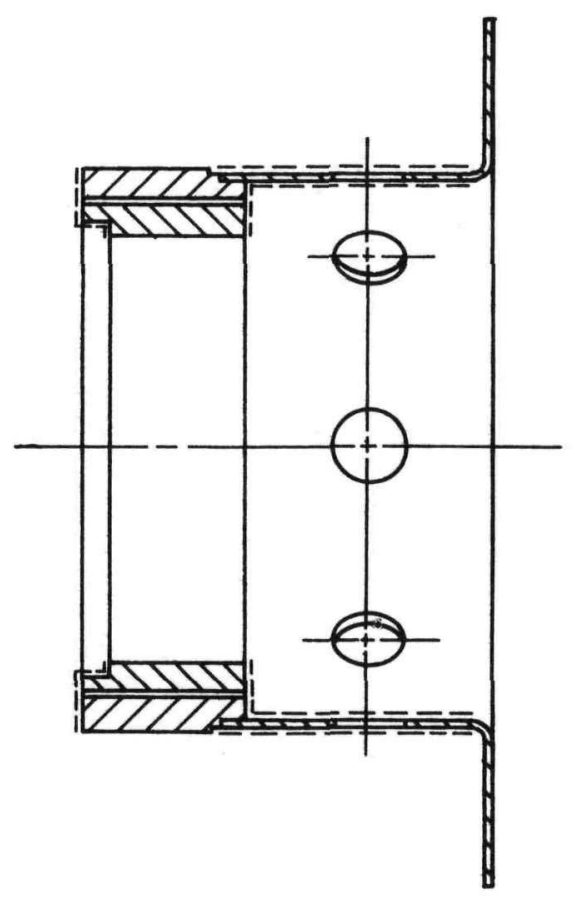

FIGURE 9 - Emitter Lead Sub-Assembly 


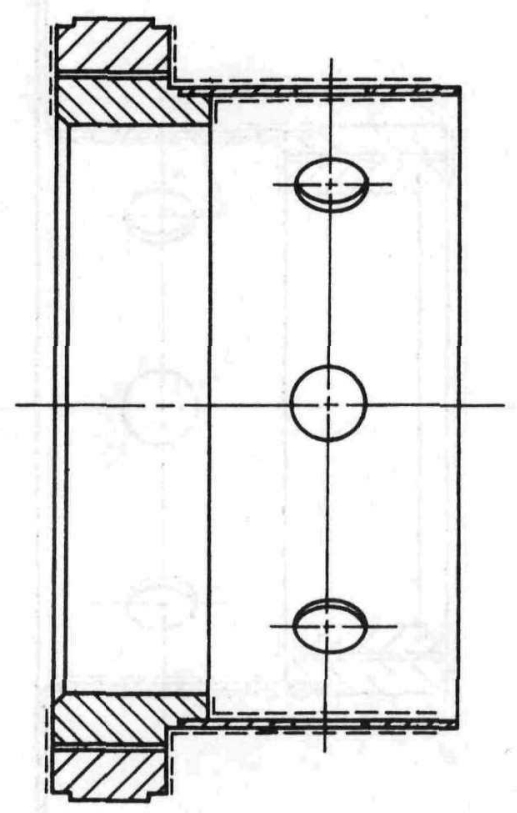

FIGURE 10 - Collector Lead Sub-Assembly 


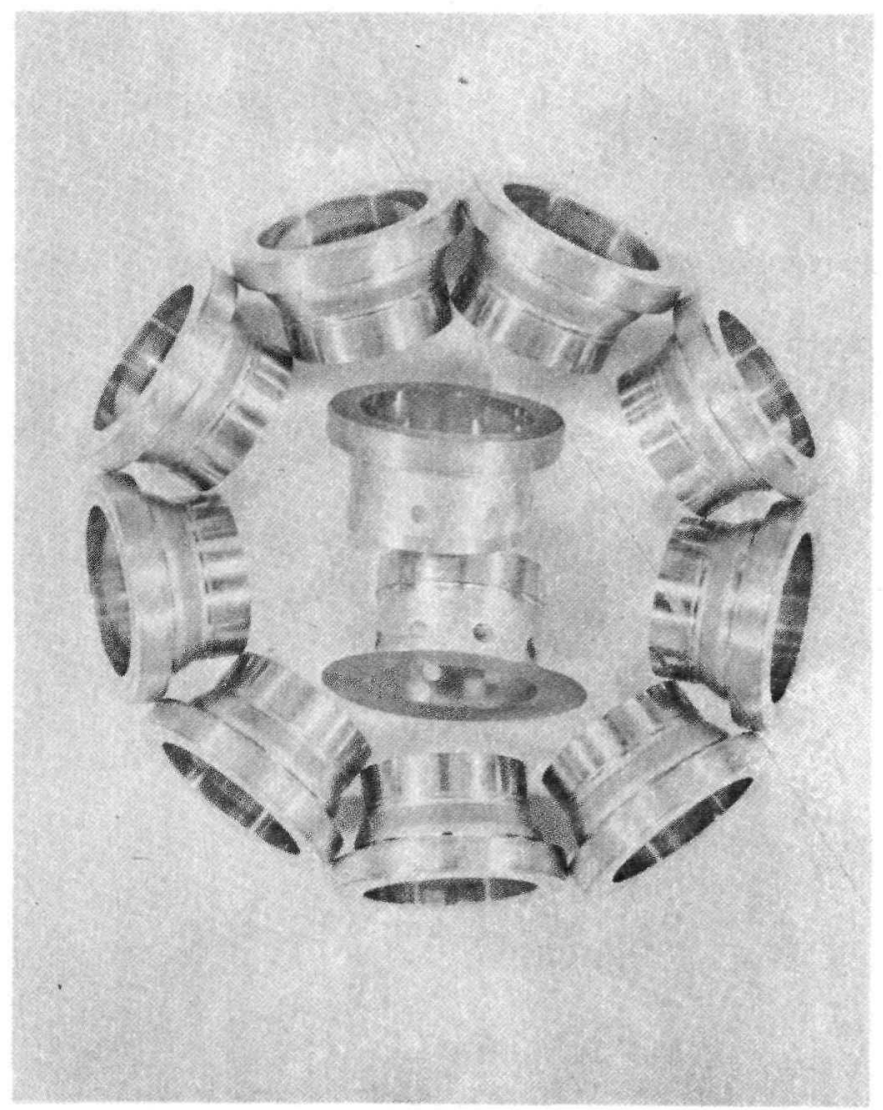

Emitter/Collector Tri-Layer Sub-Assemblies FIGURE 11 
3. Interelect

The lead connecting the emitter of one converter to the collector of the following converter assembly was designed to carry out several functions in addition to the inter-connection of successive electrodes. Through the use of spiralling radial slots, the lead can be utilized to relieve the axial differential expansion, due to temperature difference, between the emitter and collector columns. By varying the number of spiralled radial slots, the width between the slots and the length of the slots, the correct area-to-length relationship for optimum converter performance at a particular operating temperature can be achieved. A design was completed in which these functions were accomplished by the interelectrode lead. The details of this design are shown in Figure 12. The leads were drawn from 0.020 inch thick, deep drawing quality, Universal Cyclops molybdenum sheet. The slotting was performed with an abrasive cutting wheel and the fixture shown in Figure 13. This fixture held both electrodes in perfect concentric alignment during the slotting operations.

4. Auxiliary Sub-Assembly_Design and Fabrication

The closure of the module units to the heat pipe at both ends, connection and support of the respective power leads, and electrical isolation of the power leads from the heat pipe was accomplished by the sub-assembly design shown in Figure 14. This assembly was welded directly to the heat pipe assembly to complete the module vacuum envelope. The end diaphragm served to accommodate differential 


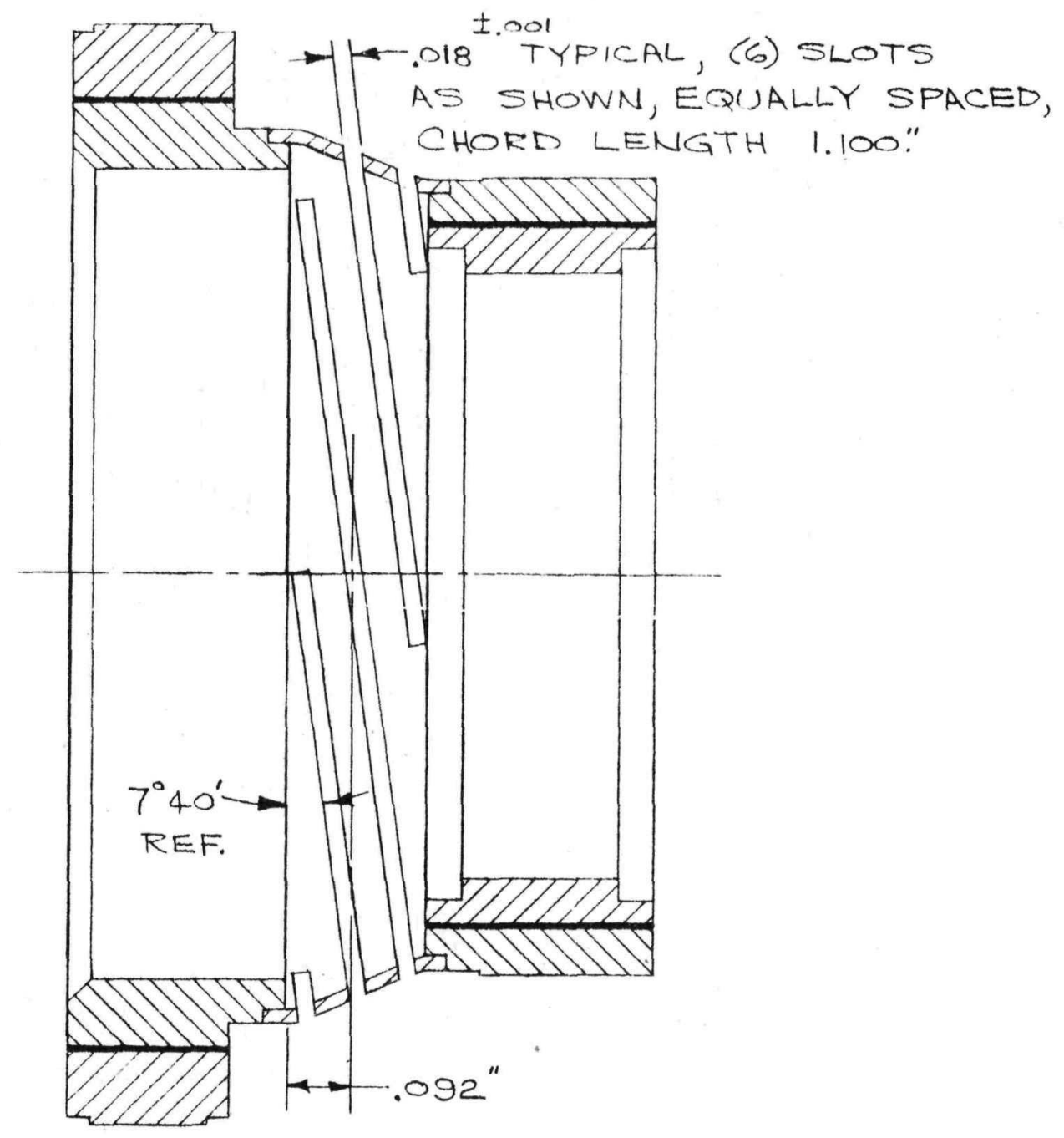

FIGURE 12 - Interelectrode Lead Slotting Details 

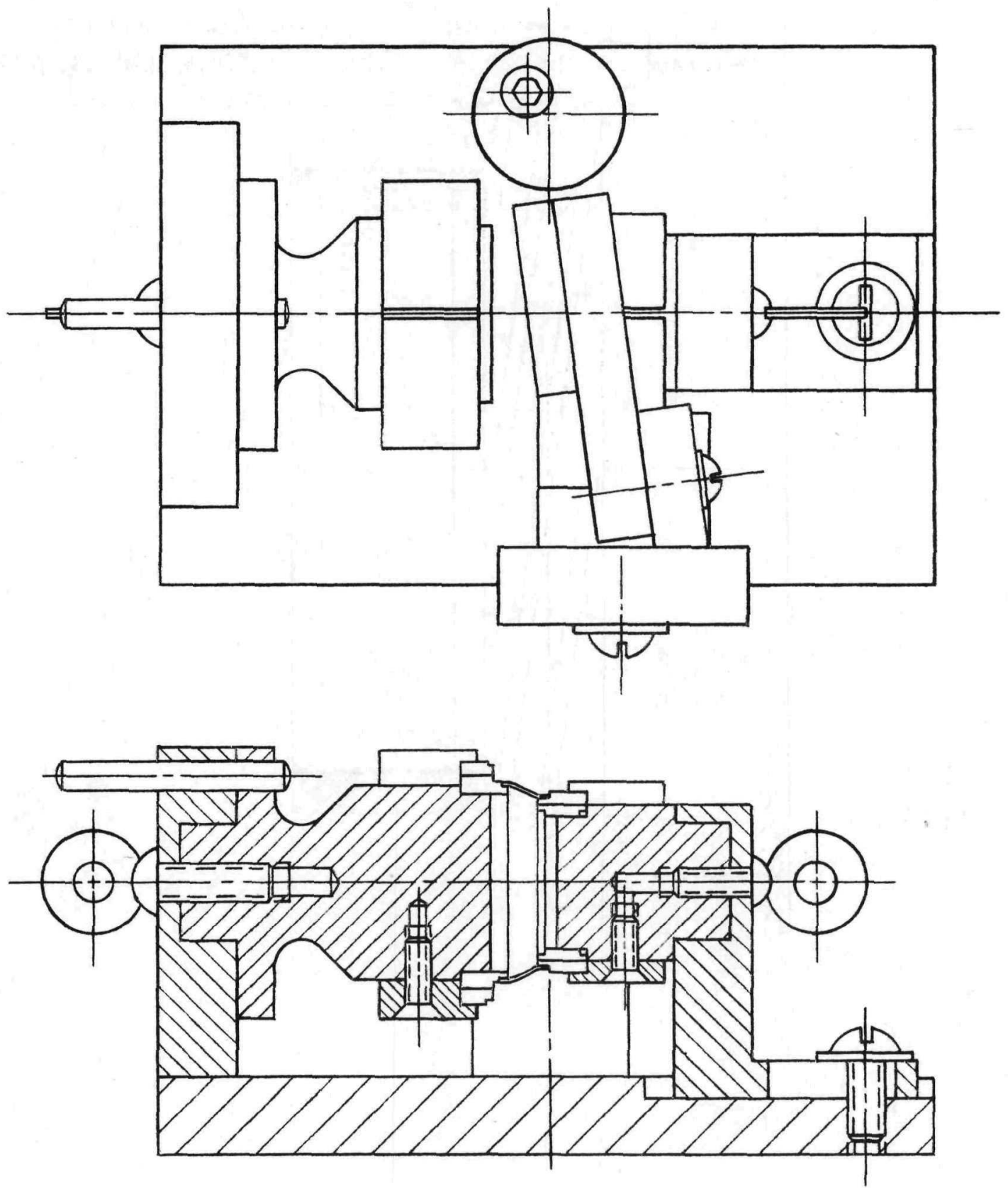

FIGURE 13 - Interelectrode Slotting Fixture 

expansion due to temperature difference between the heat pipe and converter columns. The power output leads were molybdenum, brazed to the sub-assembly with iron-palladium brazing alloy.

5. Exhaust Tubulation_Sub-Assembly Design_and_Fabrication

The exhaust tubulation was positioned at the mid-point of the module. This sub-assembly is shown in Figure 15. The exhaust tubulation was $3 / 16$ inch $0 . D$. with a 0.020 inch wall thickness. This tubing was brazed to the adaptor ring with iron-palladium brazing alloy. The exhaust appendages were later attached to the tubulation using copper as the brazing alloy.

\section{Arc supression Coating}

The internal module areas which are subject to voltage break-down were coated with the alumina/yttria coating developed under Contract AT(30-1)-3979. The average thickness of this coating was 0.004 inches. An evaluation of the coating following subsequent welding and/or brazing cycles proved the coating to be adequate for the application. A scanning electron microscope photograph of this coating is shown in Figure 16.

\section{Module Assembly}

A basic assembly procedure was developed which utilized the technology established under Contract $\operatorname{AT}(30-1)-3979$, the two major concerns in establishing the necessary assembly techniques are the maintenance of accurate interelectrode spacing and the axial movement of the emitter/ collector sub-assemblies along the heat pipe O.D. with minimum clearance. 


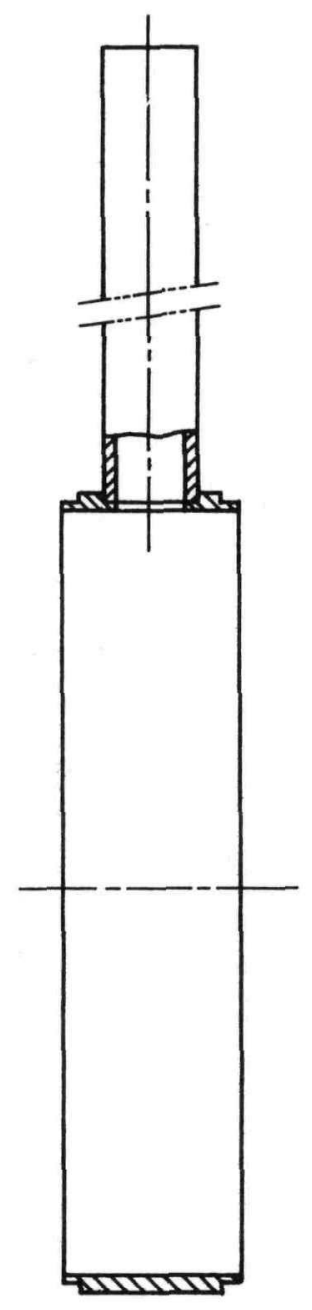

FIGURE 15 - Exhaust Tubulation Sub-Assembly 


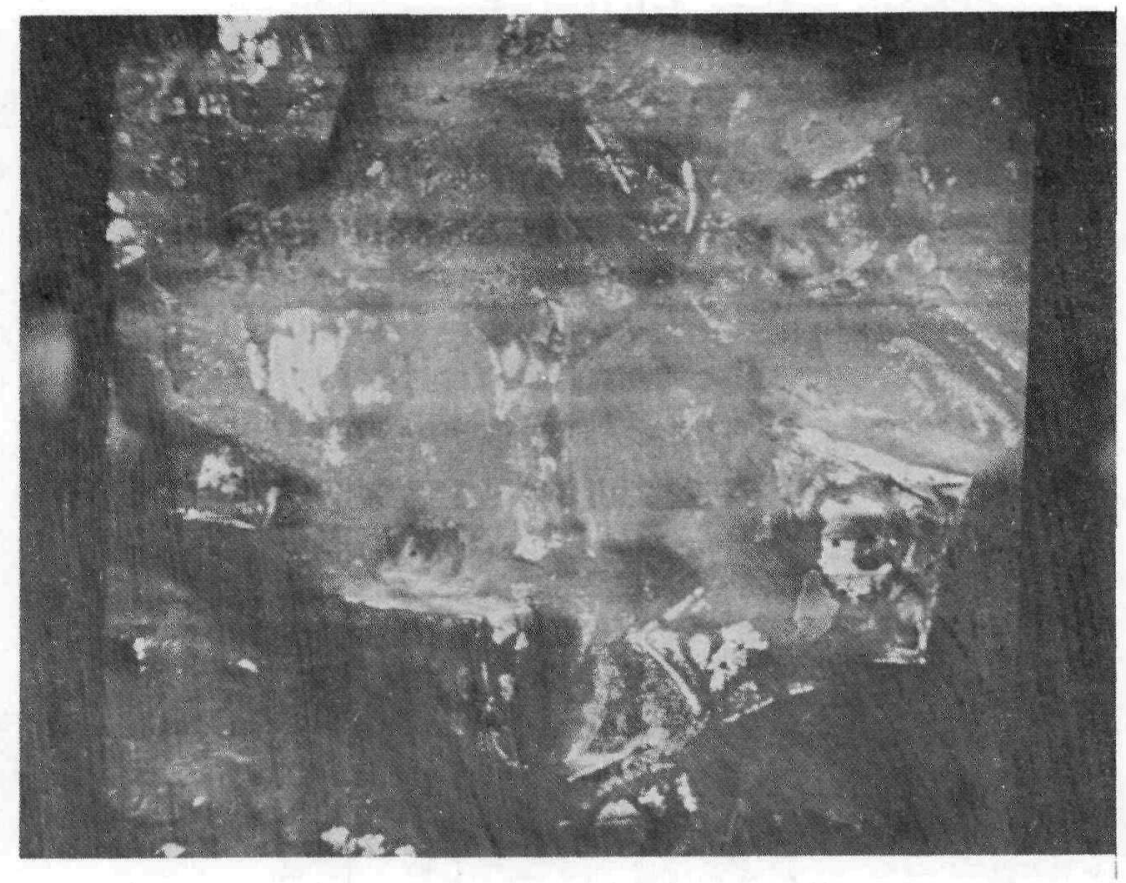

Scanning Electron Microscope Photograph of Aluminum/Yttria Arc-Suppression Coating (Magnification-500X)

FIGURE 16 
These requirements were met through proper fixturing and surface preparation.

1. Electrode Sub-Assembly_Final_Machining

Following the slotting and coating of the emitter/collector trilayer sub-assemblies, the electrode surfaces were final machined. This procedure insured the maintenance of close tolerance and provided a clean surface free of any processing contaminents. Approximately 0.005 inch was removed from each electrode surface and all jigging surfaces rechecked to insure concentricity and parallelism in the appropriate areas. The sub-assemblies were then stored in a "clean area" to await final assembly onto the heat pipe.

\section{Assembly_Procedure}

Following the completion of the various sub-assemblies and module components, the final assembly was started. A flow chart showing the order of assembly is given in Table I. The order of assembly is shown starting at the heat pipe lead-end (bottom half) and progressing upward to the final weld of the top end-cap diaphragm and heat pipe extension. The principal sub-assemblies and components are shown in Figures 17 through 25, respectively. The sub-assemblies were "stacked" onto the heat pipe in the respective order shown in Figure 3 of this report. A molybdenum welding fixture was employed to set the spacing between the heat pipe surface and the collector surface of the assembly being welded to the respective collector 


\section{MODULE FLOW CHART}

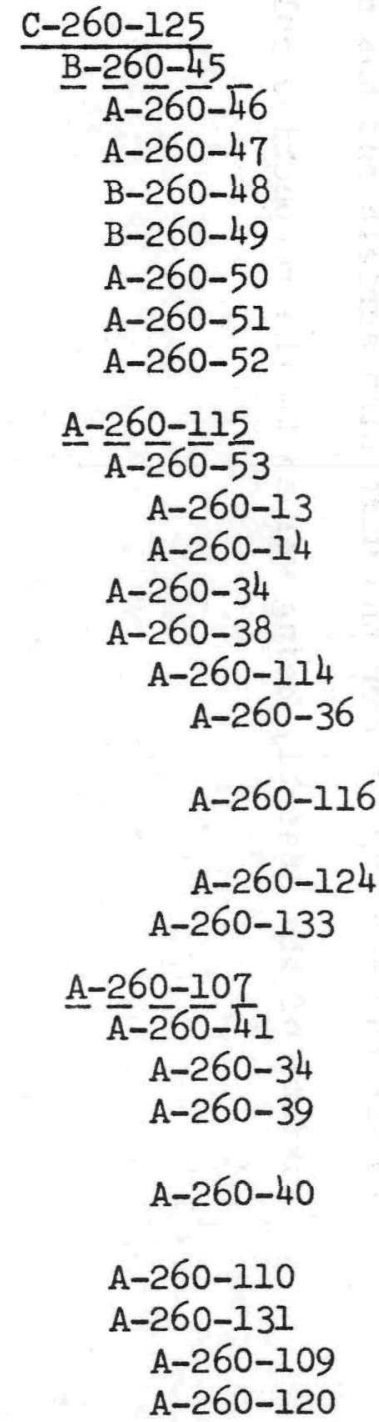

Fabrication Model (Ass'y.)

Heat Pipe Sub-Ass'y.

Heat Pipe Extension

Orifice Cap

Condenser Section-Heat Pipe

Evaporat or Section-Heat Pipe

Center Lead-Heat Pipe

End Lead-Heat Pipe

End Cap

Diaphragm Sub-Assembly

Diaphragm

Bottom Half-Diaphragm

Top Half-Diaphragm

Ceramic Insulator

Outer Lead Assembly

Lead Adapter Sub-Assembly

Lead Strain Isolation Flange 2

(Made from A-260-2)

Lead Isolation Ring

(Made from A-260-2)

Outer Lead Adapter

Solid Lead

Collector Lead Assembly

Ceramic Isolation Sub-Assembly

Ceramic Insulator

Strain Isolation Ring

(Made from A-260-2)

Short Strain Isolation Flange

(Made from A-260-2)

1

collector Lead Cup

Collector Lead Sub-Assembly

Collector Lead Sleeve

Mach. End Collector Tri-Layer

(Made from A260-99) 


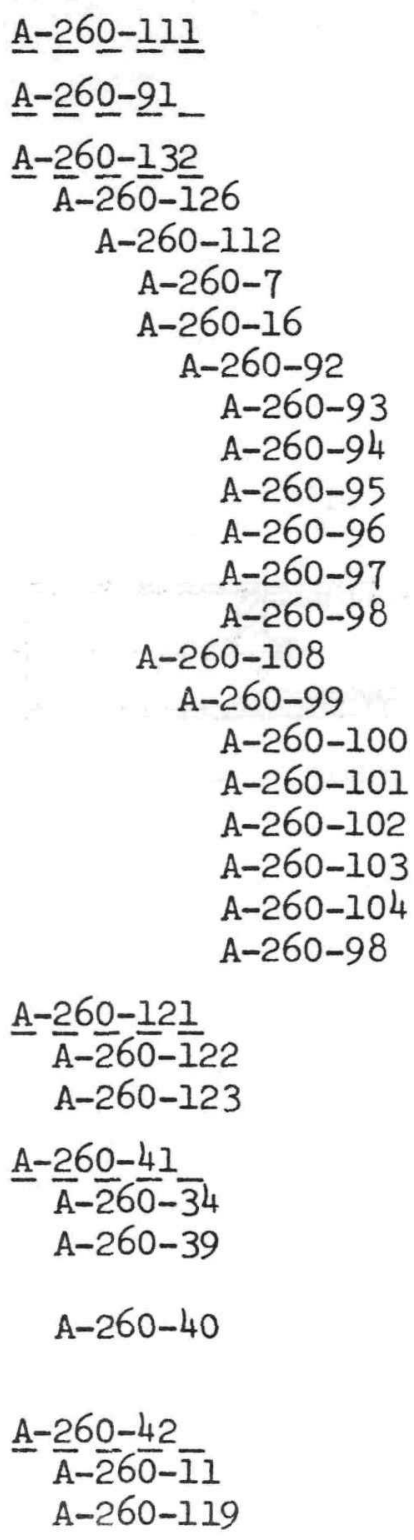

Collector Connector 8

Emitter Ceramic Spacer 9

Coated Emitter-Collector Assembly 9

Slotted Em.-Col. Assembly 9

Emitter-Collector Assembly

Interelectrode Lead 9

Machined Emitter Tri-Layer 9

Cast Emitter Assembly Outer Emitter Tog.

Inner Emitter Tbg.

Emitter Bottom Plug -

Emitter Bottom Cap -

Emitter Top Plug

Casting Vac. Tog.

Machined Collector Tri-Layer 9

Cast Collector Assly

Outer Collector Tbg.

Inner Collector Tbg.

Collector Bottom Plug

Collector Bottom Cap

Collector Top Plug

Casting Vac. Tbg.

Exhaust Tubing Sub-Assembly

Exhaust Tubing

Exhaust Tubing Ring

Ceramic Isolation Sub-Assembly

Ceramic Insulator

Strain Isolation Ring

(Made from A-260-2)

Short Strain Isolation Flange

(Made from A-260-2)

Emitter Lead Sub-Assembly

Emitter Lead

Mach. End Emitter Tri-Layer

(Made from A260-92) 
$\stackrel{\infty}{N}$

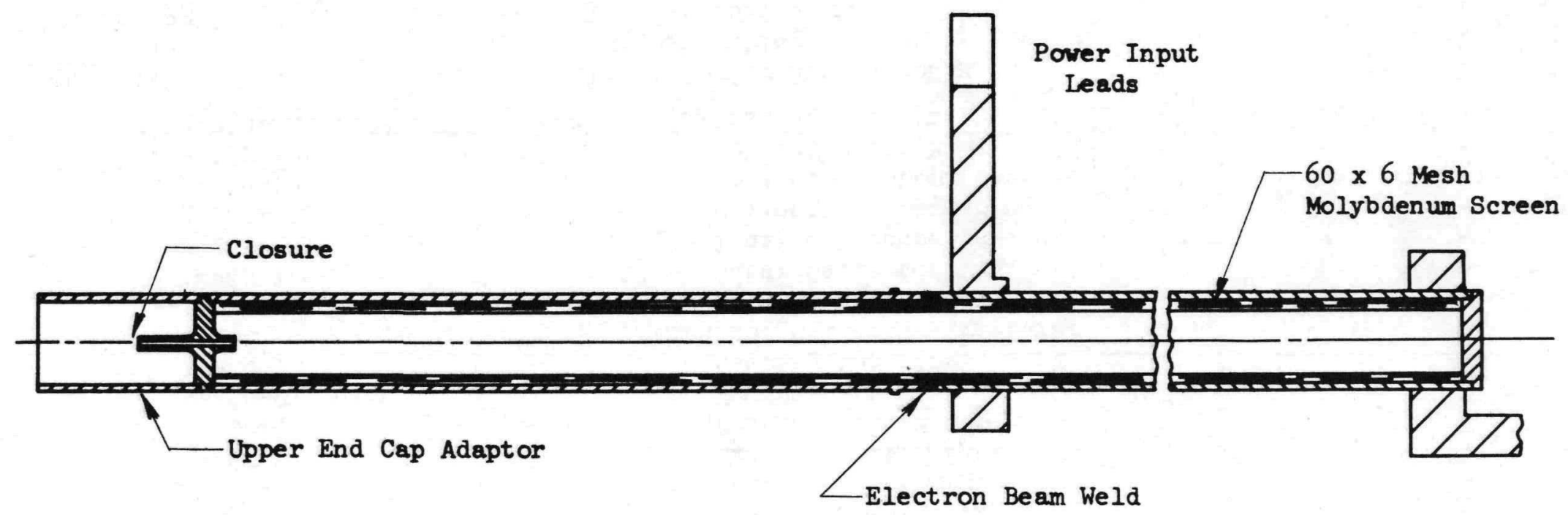

FIGURE 17 - Module Heat Pipe Sub-Assembly 


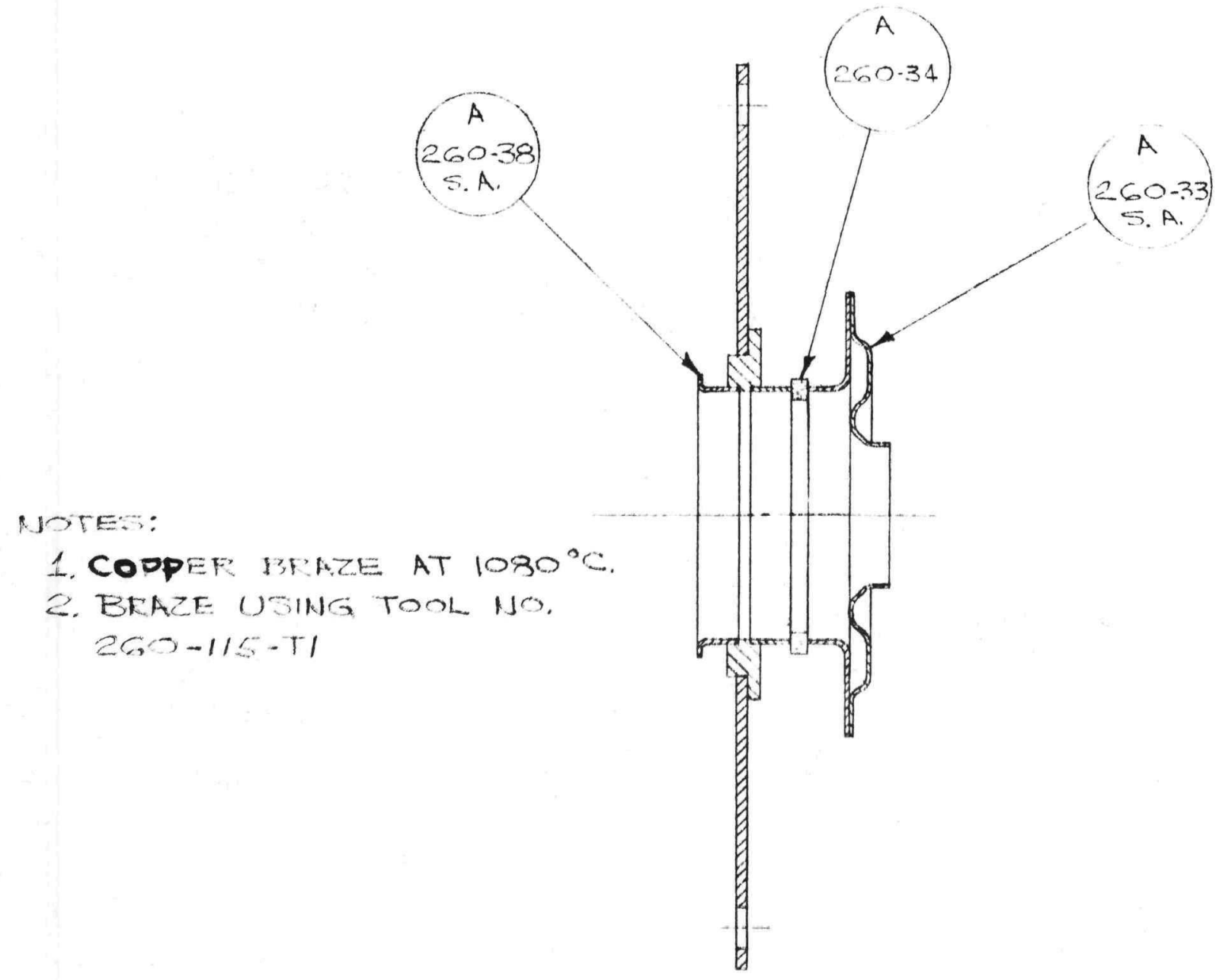

FIGURE 18 - Lower Diaphragm and Collector Power Lead Sub-Assembly 


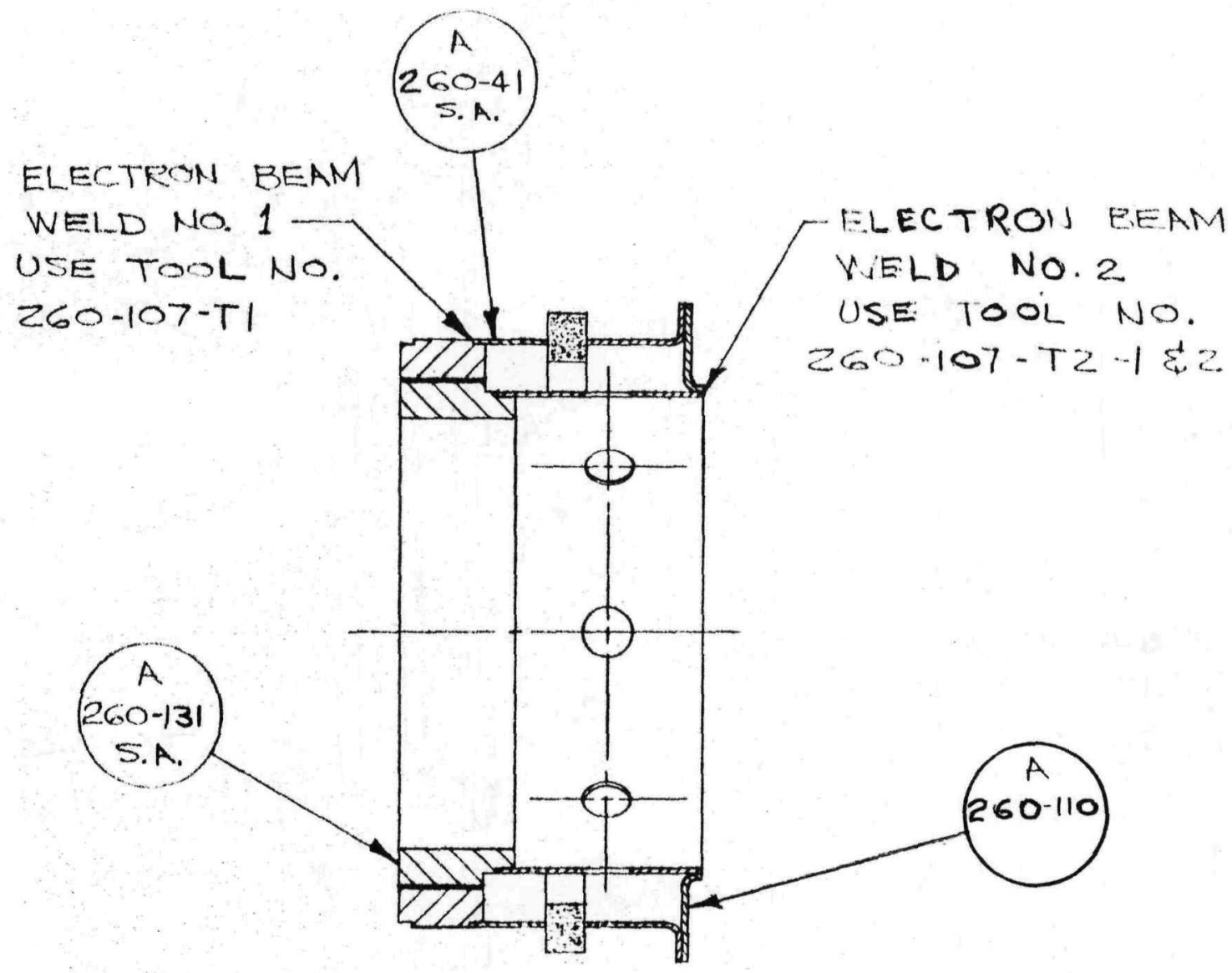

FIGURE 19 - Collector Lead Sub-Assembly 


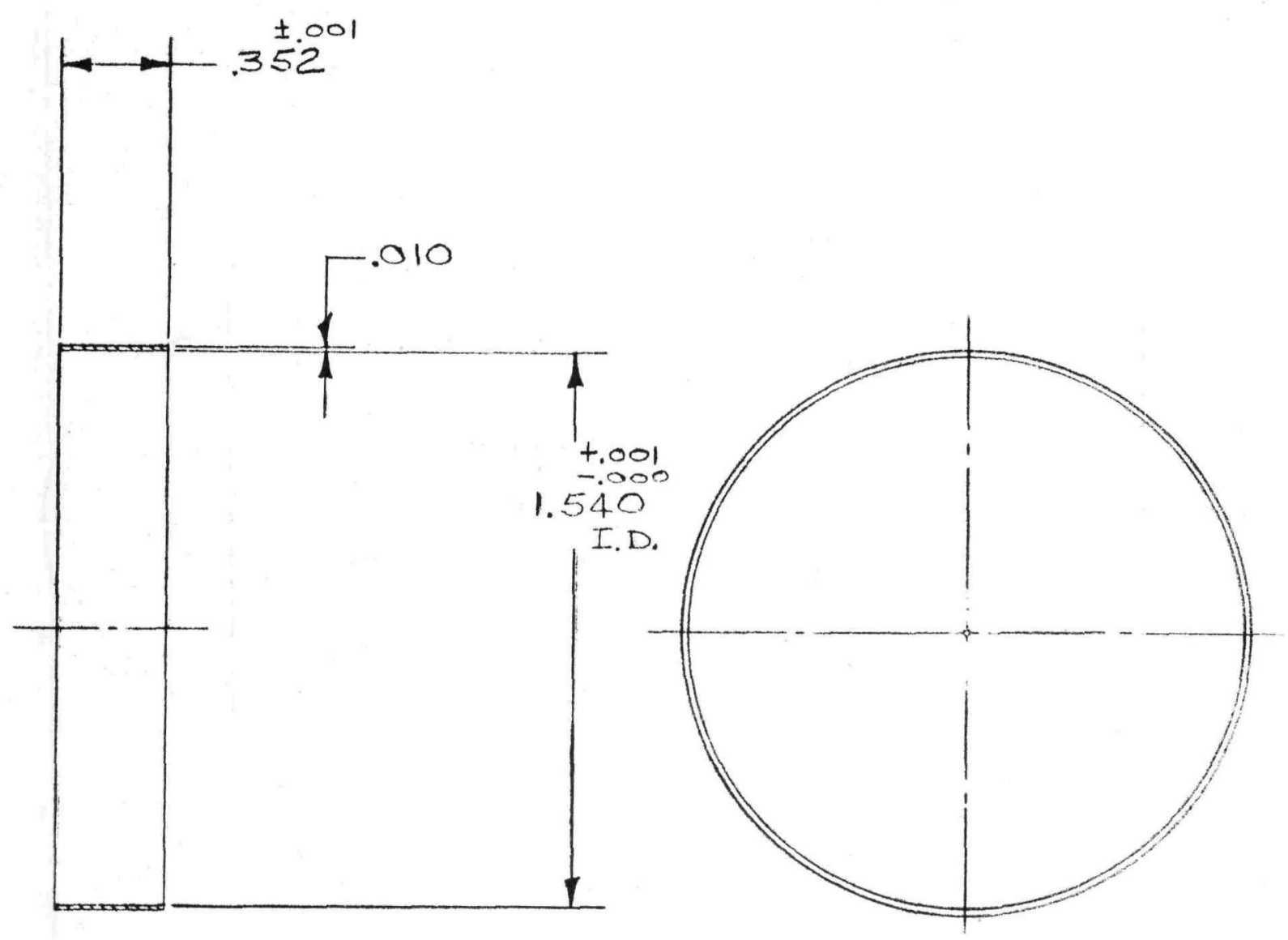

FIGURE 20 - Collector Interconnecting Ring 


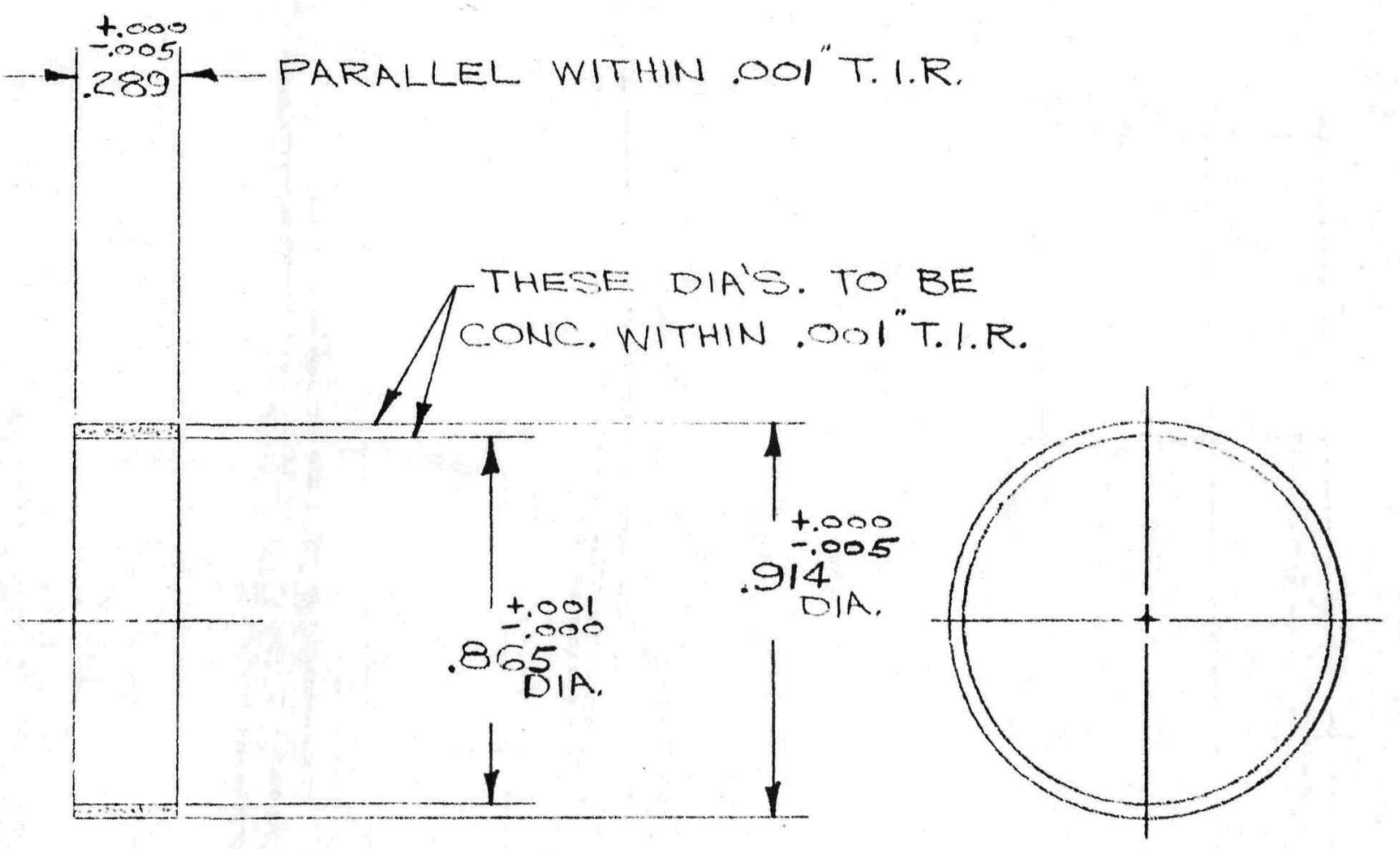

FIGURE 21 - Emitter Ceramic Spacer 


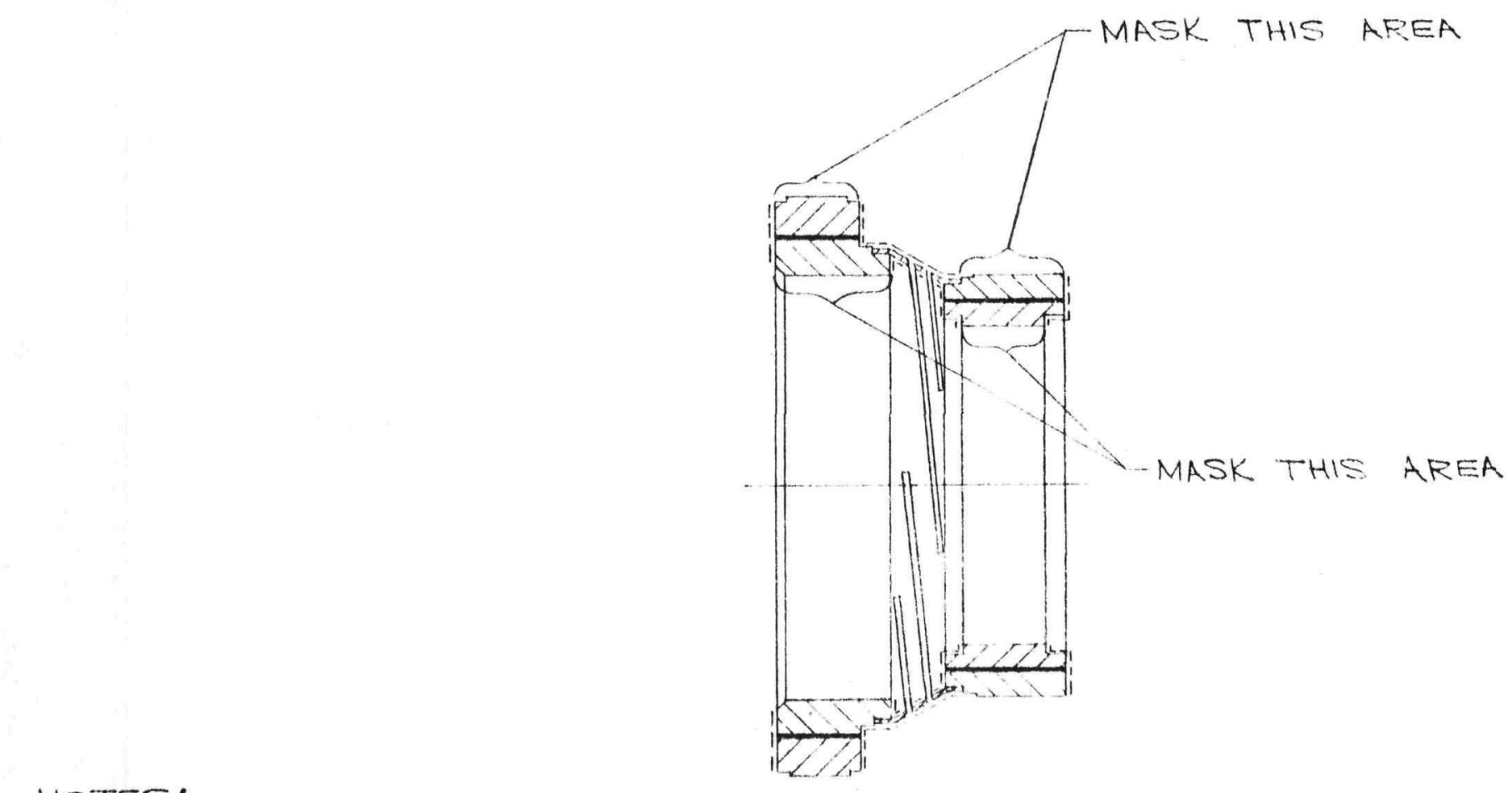

NOTES:
1. COAT SURFACES INDICATED $(\cdots)$ WITH $\mathrm{Al}_{2} \mathrm{O}_{3}$

FIGURE 22 - Emitter-Collector Assembly 


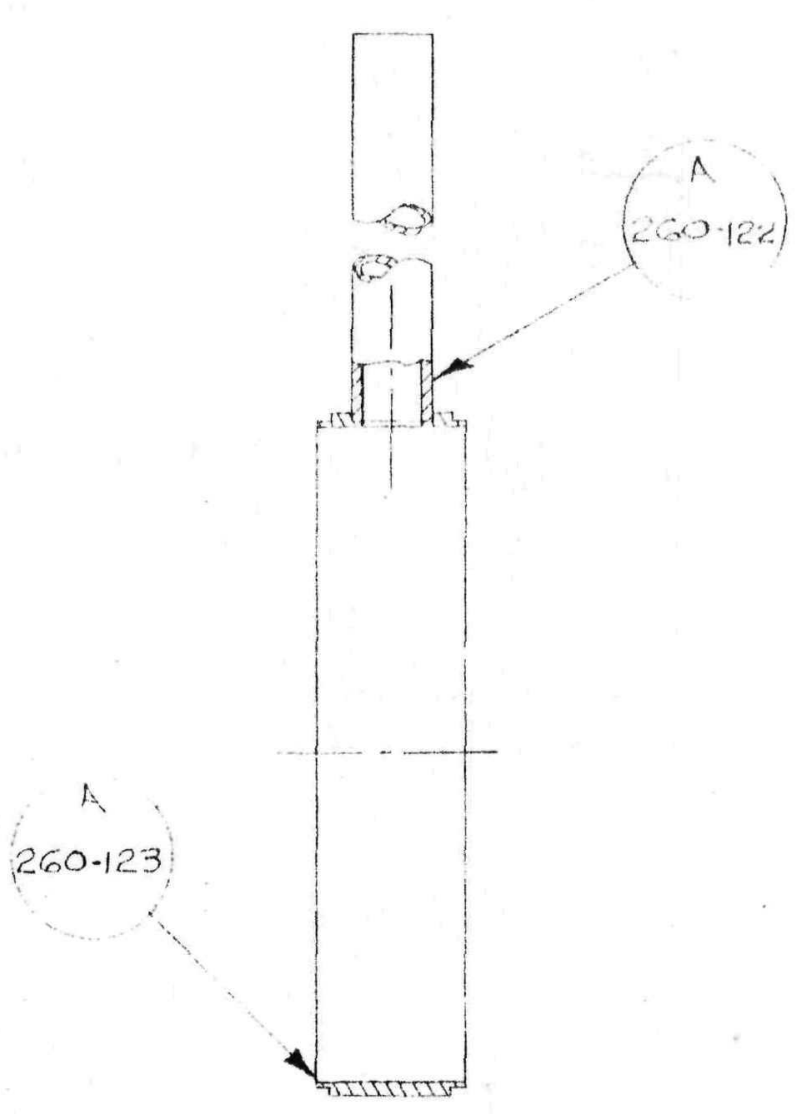

NOTES:

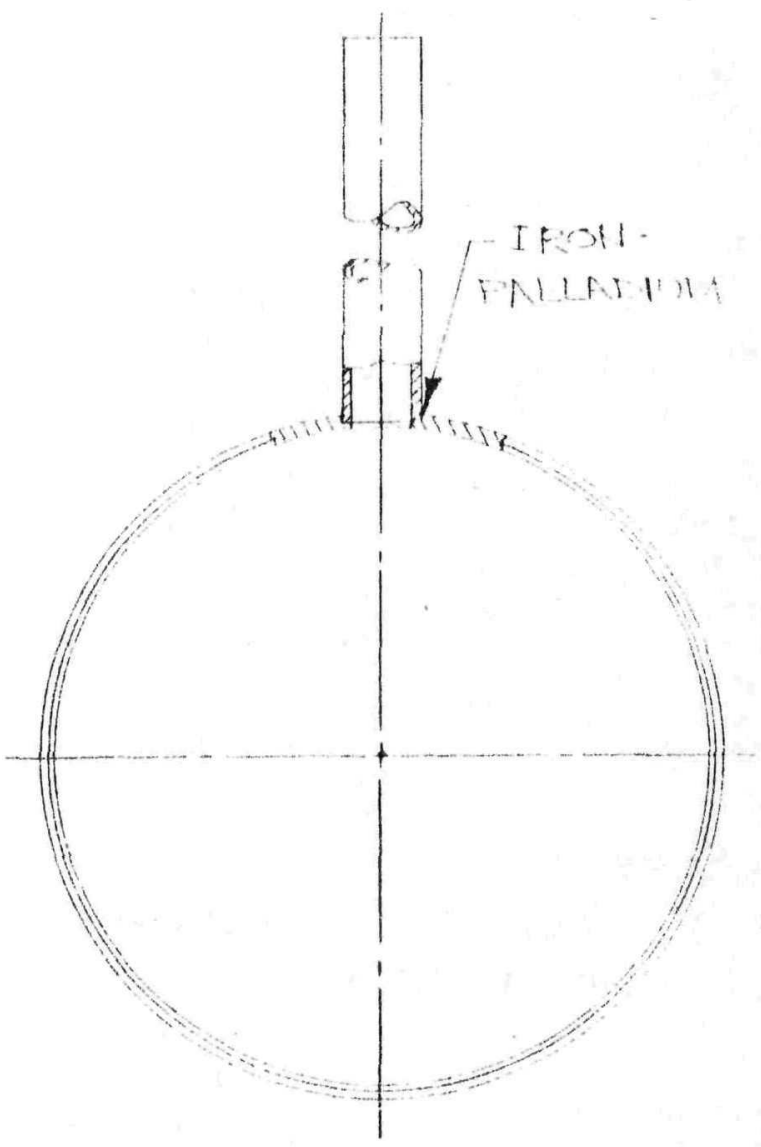

1. BRAZE IN VAC. AT $1350^{\circ} \mathrm{C}$.

FIGURE 23 - Exhaust Tubing Sub-Assembly 


\section{NOTES:}

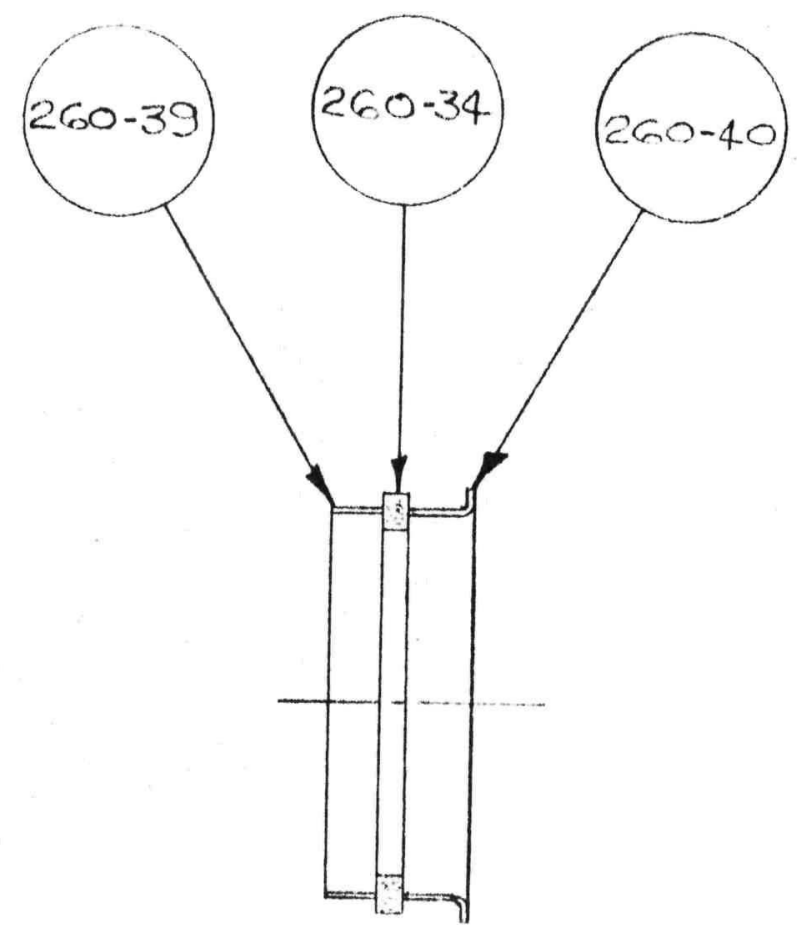

FIGURE 24 - Ceramic Isolation Sub-Assembly 


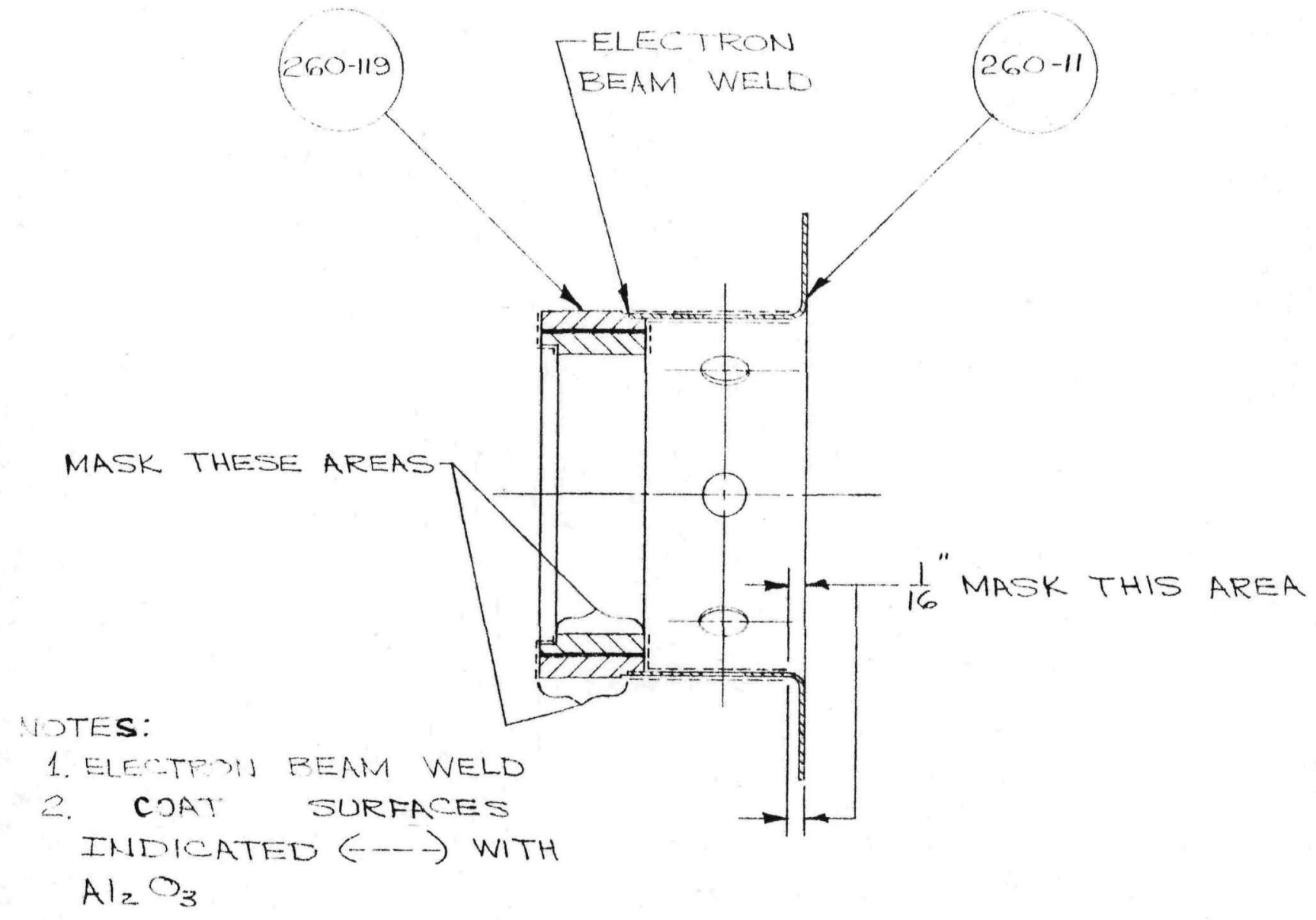

FIGURE 25 - Emitter Lead Sub-Assembly 
interconnecting ring. The next emitter/collector sub-assembly is then set in place, with the emitter sliding between the heat pipe and collector of the previous assembly with the proper emitter-collector spacing.

The original module assembly technique was altered in that the collector-to-collector interconnecting ring jointure was made by local induction heating for copper brazing $\left(1080^{\circ} \mathrm{C}\right)$. This change was instituted to prevent any likely damage of the arc-suppression coating in the weld area adjacent to the collector-collector interconnecting ring joint. The same fixturing for determining electrode spacing was employed. The brazing operation employed utilized a carbon ring as a radiator source to reduce the likelihood of severe temperature non-uniformity. Thus the jointure was made by radiating heat from the carbon ring to the components being brazed. This technique also necessitated nickel plating the respective brazing areas to enhance wetting of the braze material to the molybdenum. Several test brazes were made prior to actual assembly in order to develop the proper furnace settings.

The module assembly was initiated using this brazing technique. The assembly was leak checked following each brazing operation. Successful joints were made on the first seven converter assemblies. However, on the eighth assembly, the brazing fixture froze to the collector assembly, necessitating the removal of this assembly. This required 
the remachining of the brazing area for the previous assembly to insure concentricity and parallelism. The unit was set up and rebrazed. Upon leak checking it was determined that the exhaust tubing sub-assembly had developed a leak. Numerous attempts were made to rebraze this area with the same copper brazing alloy. However, new leaks developed due to the thermal cycling in these areas. It was decided that a rebrazing attempt should be made with a lower temperature alloy such as niaro $\left(930^{\circ} \mathrm{C}\right)$ in order to salvage the assembly for minimum testing and concept evaluation. These rebrazing attempts proved to be successful and the final converter assemblies were added. During the final brazing of these units, additional leaks developed near the center of the module. Additional attempts to rebraze the assembly proved unsuccessful and no further work was conducted with the assembly.

3. Assembly_Technique_Analysis

The original collector-collector interconnecting ring joint was designed to be welded using the electron-beam welding technique. Therefore the collector joint had a small step for holding the interconnecting ring during this welding. When the decision was made to make this joint by a brazing technique, the parts and sub-assemblies were already completed, thus making redesign of the joint unfeasible. The design of this joint, from a brazing point of view, was not optimum. The small step made the use of flat brazing washers almost impossible. Ring brazing forms were also 
difficult to handle since extremely small wire had to be employed. As a result, small brazing material fillets developed with only surface line contact jointure at best, in many cases. The nickel plating added also enhanced the chance of leak development through blisters and added impurities.

\section{Task II - Advanced High Voltage Module Technology}

The objective of this task was to continue efforts for the improvement and advancement of technology surrounding the high voltage module concept. The major areas of concern included tri-layer fabrication, and arc-suppression coatings.

\section{A. Tri-Layer Technology}

A program of continued tri-layer evaluation was conducted in the areas of welding, machining and interelectrode lead slotting. Additional welding tests were performed, using the accepted interelectrode lead. These leads were thicker $(0.020$ inch) and required greater electron-beam welding power, thus jeopardizing both the alumina layer and arcsuppression coating. These weld tests, however, showed a far superior weld with no lead buckling or local burn-through; cross-sections of the alumina layer also confirmed that no damage resulted due to the increased welding power.

Machining tests were conducted using actual end-use sub-assemblies to determine the accuracy and reproducibility of the technique developed. In all cases tried, accuracy of \pm 0.0005 inch T.I.R. could be achieved repeatedly. The electrode surface finish was more than satisfactory. 
Lead slotting techniques evaluated included electrical discharge machining and abrasive wheel machining. The tests conducted using the electrical-discharge machining technique showed non-uniformity in slot width. It is believed that this was due to the radius and taper of the lead to be slotted. Attempts were made to correct this by contouring the tool to match the part. The quality was improved, but was inferior to those parts fabricated using the abrasive wheel technique. The abrasive wheel technique was therefore used for actual parts fabrication.

\section{B. Arc Sunnression Coatings}

While an adequate coating for arc-suppression was developed on Contract $\operatorname{AT}(30-1)-3979$, efforts were continued to develop an improved application method for coating the complex emitter/collector assembly. This effort included the improvement of the previously developed alumina/yttria coating and the investigation of a "sputtering" technique for aluminum oxide.

\section{Alumina/Yttria_Coating}

The application of the alumina/yttria coating involved the thermal cycling of the subject parts and sub-assemblies to temperatures as high as $1800^{\circ} \mathrm{C}$. This spray/sinter technique required careful masking and surface preparation to insure a completely impervious coating. Through the use of improved spraying fixtures the required masking was substantially reduced. It was also determined that the sintering temperatures could also be somewhat reduced (approximately $1725^{\circ} \mathrm{C}$ ) without sacrificing the quality of the coating. The most 
critical area for coating was the tri-layer end-area. Small

"chipped-out" areas of $\mathrm{Al}_{2} \mathrm{O}_{3}$ were difficult to completely cover. Repeated coatings created greater than optimum thickness, and cracking resulted when the assemblies were thermal cycled. Thus only those assemblies with void-free end-areas were utilized for module use.

2. Sputtering_of Aluminum_Oxide

The uniformity of coating thickness using the sputtering technique, as well as the controlled atmosphere of the coating (vacuum), make sputtering an attractive process for arc suppression coatings. Molybdenum samples were sent to Electrotec Corporation for evaluation of the process. The first samples were coated with approximately $4000 \AA$ of aluminum oxide. These samples proved to be impervious in those areas where the surface finish was best. The coating appeared to be deposited in the exact pattern of the original surface finish. Thus rough surface finishes did not provide an impervious coating. As a result, four additional samples, 3/4" dianeter disks, were prepared with varying surface preparations to determine the effects of surface finish and preparation on final coatings. The four samples were prepared as follows:

a. Machine to 16 micro-inch finish, fire in hydrogen to $2000^{\circ} \mathrm{C}$ for 5 minutes.

b. Machine same as "a", electropolish for 3 minutes before firing saine as " $a$ ". 
c. Same as " $a$ " except dental blast before firing.

d. Same as "c" except electropolish for 3 minutes before firing.

These samples were photographed, using the scanning electron microscope before coating to record the surface finish and immediately following coating to compare the form of deposition. These photographs are shown in Figures 26 through 33 . All samples were coated to a thickness of $25,000 \AA$. From these photographs it can be seen that the deposition is completed according to the original surface finish. In general, the better the original surface finish (smoother) the better the chances of getting an impervious coating. Further evaluation was made to determine the effectiveness of sputter coating the tri-layer end-areas. Samples coated showed small void areas adjacent to the alumina layer. Since this is the most critical area, this method was not satisfactory as a coating process. Figure 34 is a photograph of the tri-layer end-area following coating with $25,000 \AA$ of $\mathrm{Al}_{2} \mathrm{O}_{3}$.

As a result of these studies, it was decided to continue with the alumina/yttria coating developed under contract $\mathrm{AT}(30-1)-3979$, with minor modifications to the firing temperature and improved fixturing for the spray/sintering operation. All module sub-assemblies and components were coated using this application method. 


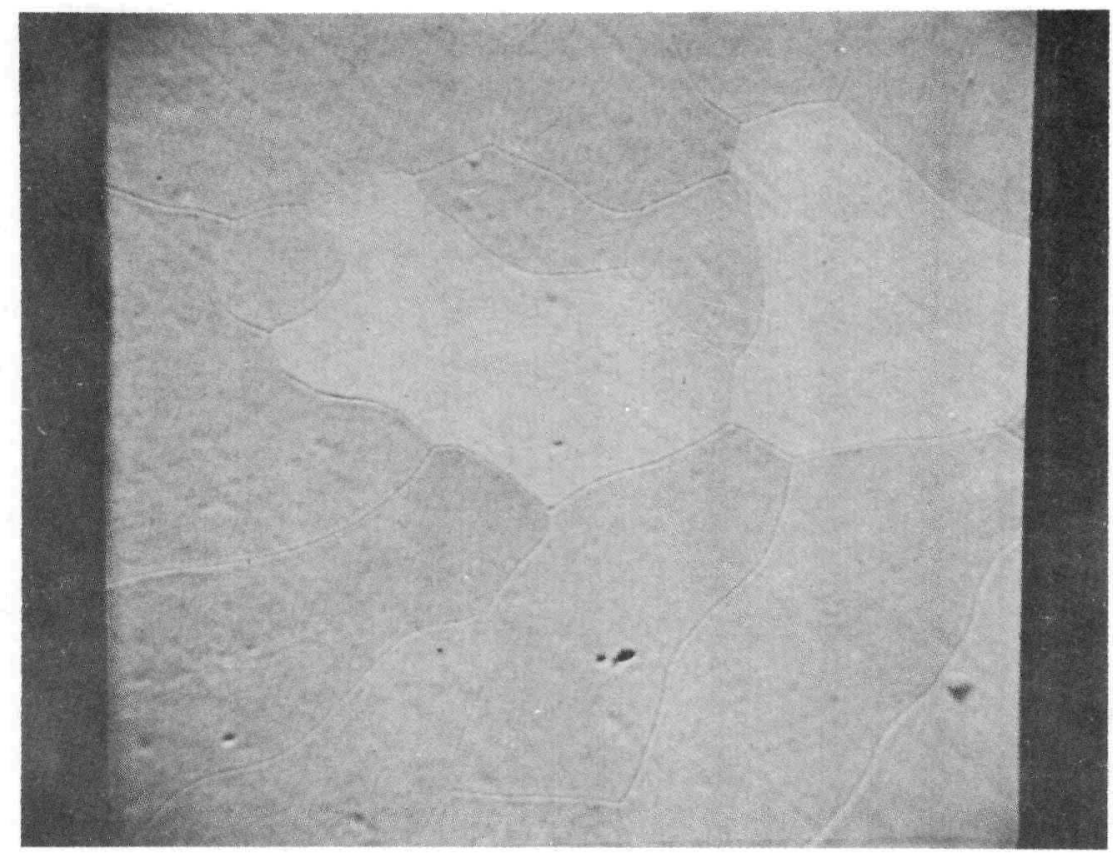

Molybdenum Sample A

Prior to Coating with $\mathrm{Al}_{2} \mathrm{O}_{3}$ - Magnification - 500X

FIGURE 26 


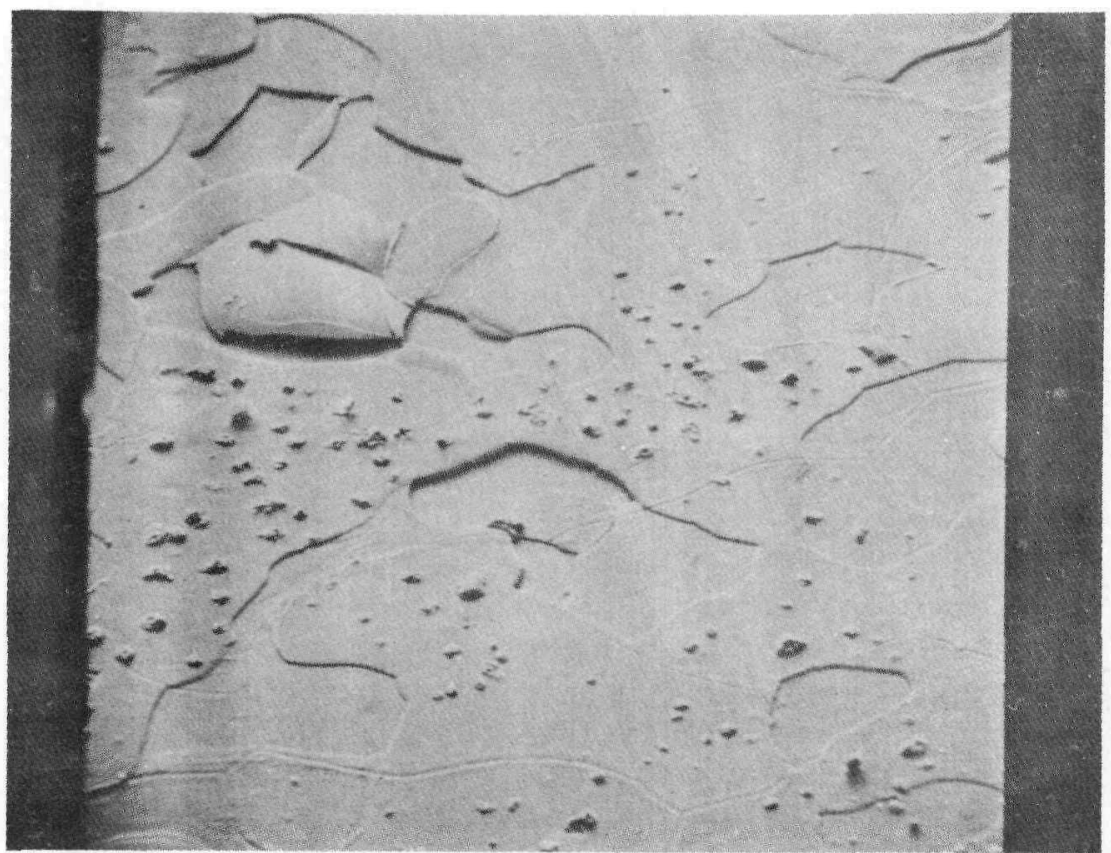

Molybdenum Sample A

After Coating with 25,000 A of $\mathrm{Al}_{2} \mathrm{O}_{3}$ - Magnification 500X

FIGURE 27 


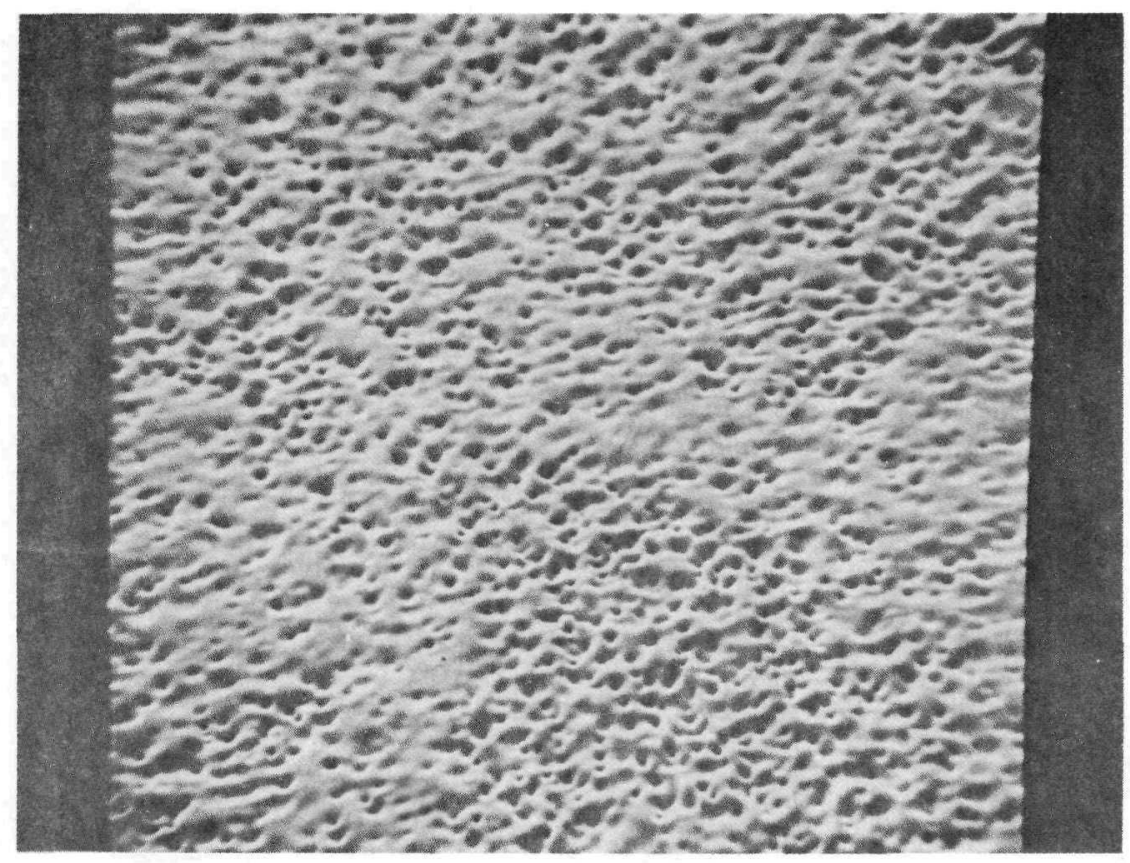

Molybdenum Sample B

Prior to Coating with $\mathrm{Al}_{2} \mathrm{O}_{3}$ - Magnification 500X

FIGURE 28 


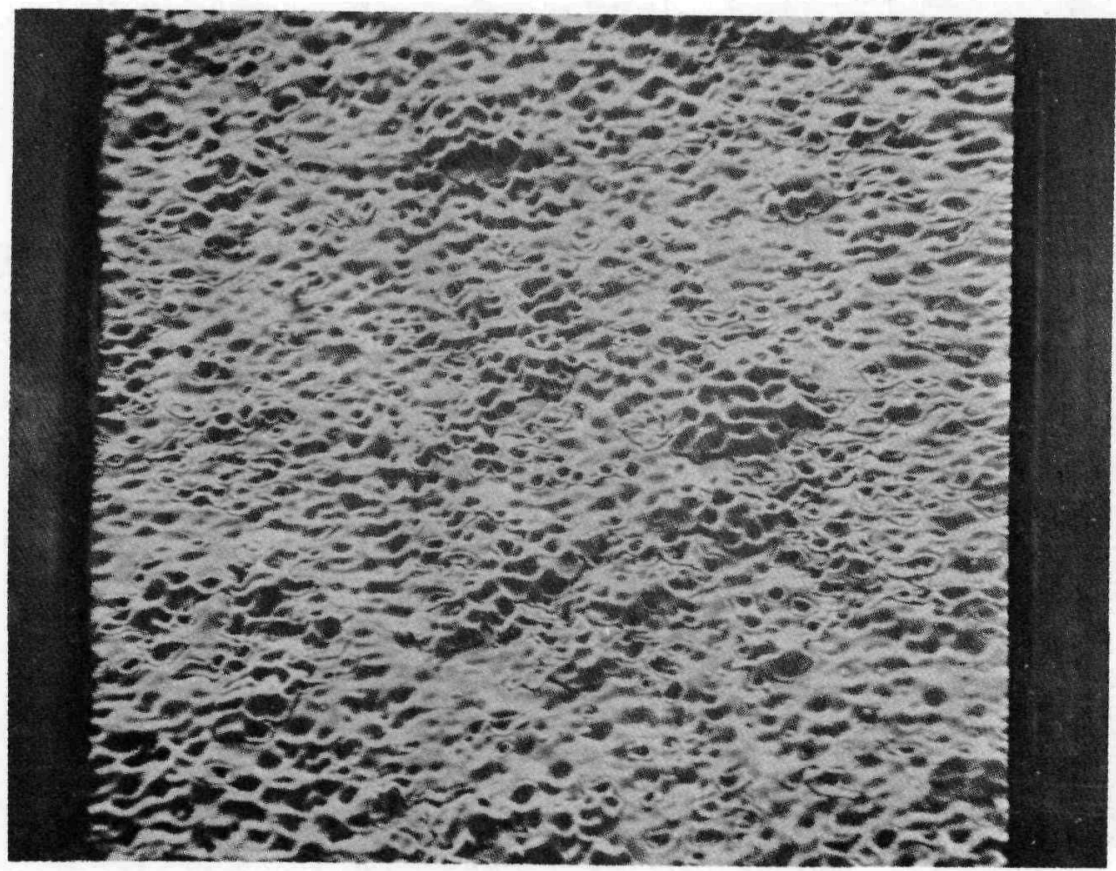

Molybdęnum Sample B

After Coating with 25,000 $\mathrm{A}$ of $\mathrm{Al}_{2} \mathrm{O}_{3}$ - Magnification - 500X

FIGURE 29 


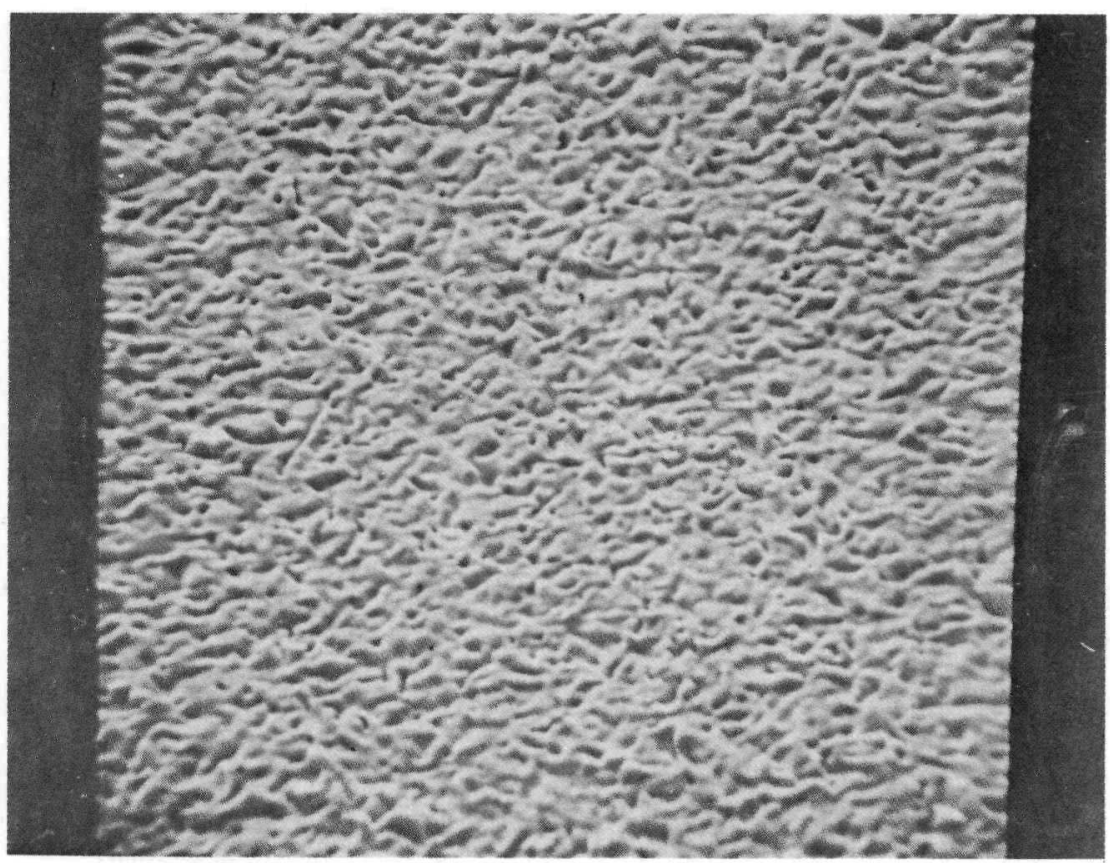

Molybdenum Sample C

Prior to Coating with $\mathrm{Al}_{2} \mathrm{O}_{3}$ - Magnification - 500X

FIGURE 30 


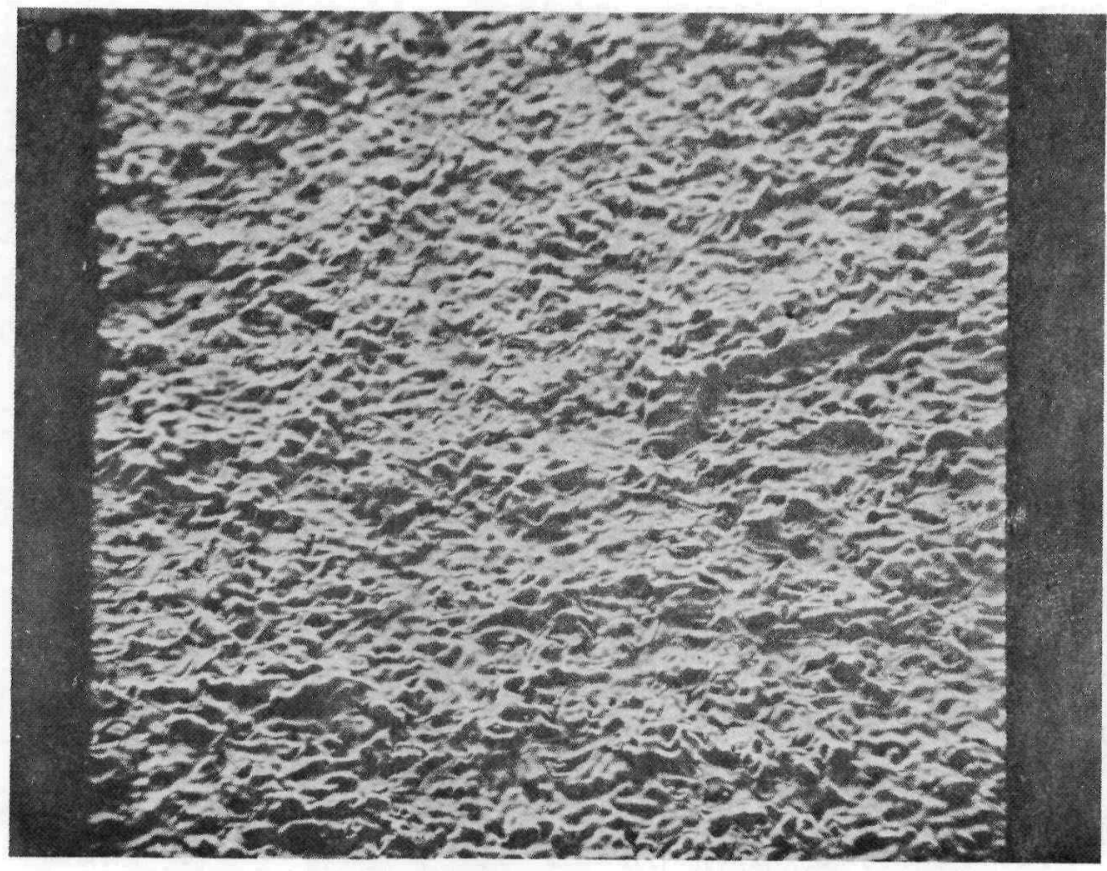

Molybdenum Sample C

After Coating with 25,000 A $\mathrm{Al}_{2} \mathrm{O}_{3}$ - Magnification - 500X

FIGURE 31 


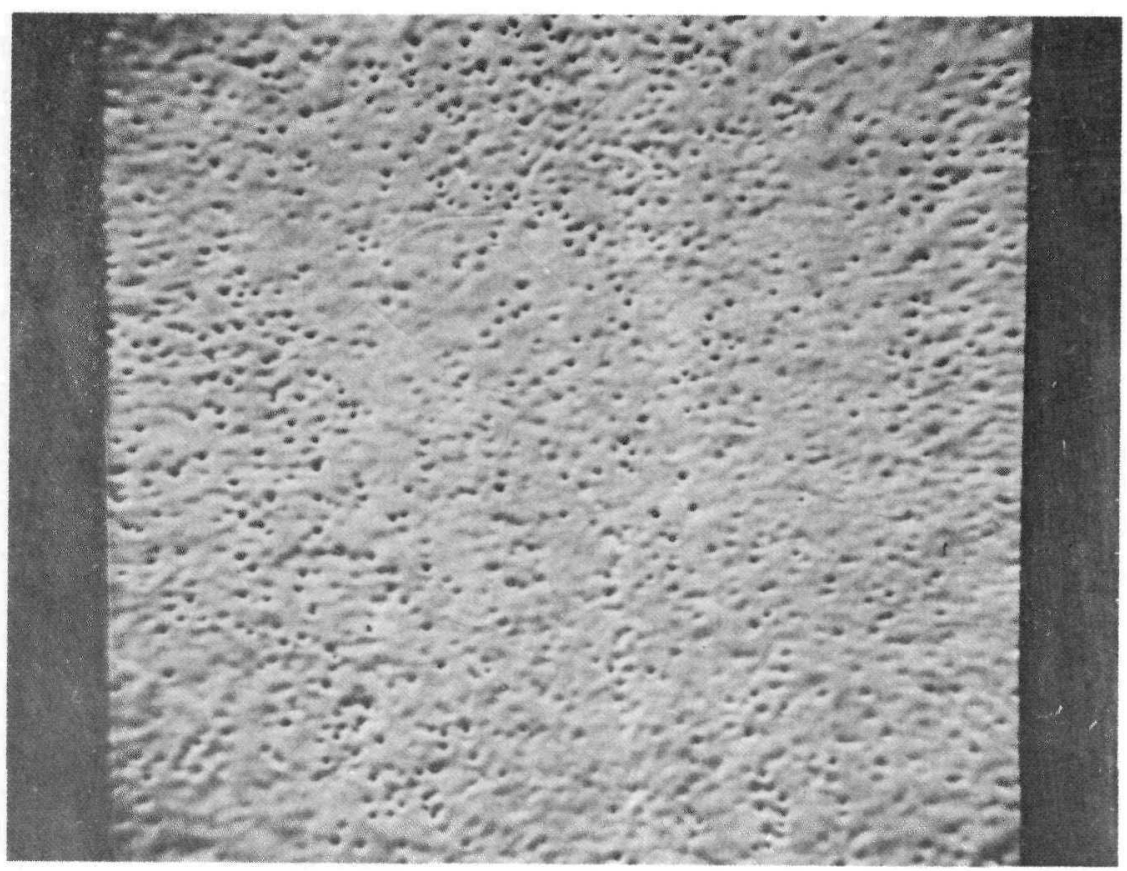

Molybdenum Sample D

Prior to Coating with $\mathrm{Al}_{2} \mathrm{O}_{3}$ - Magnification - $500 \mathrm{X}$

FIGURE 32 


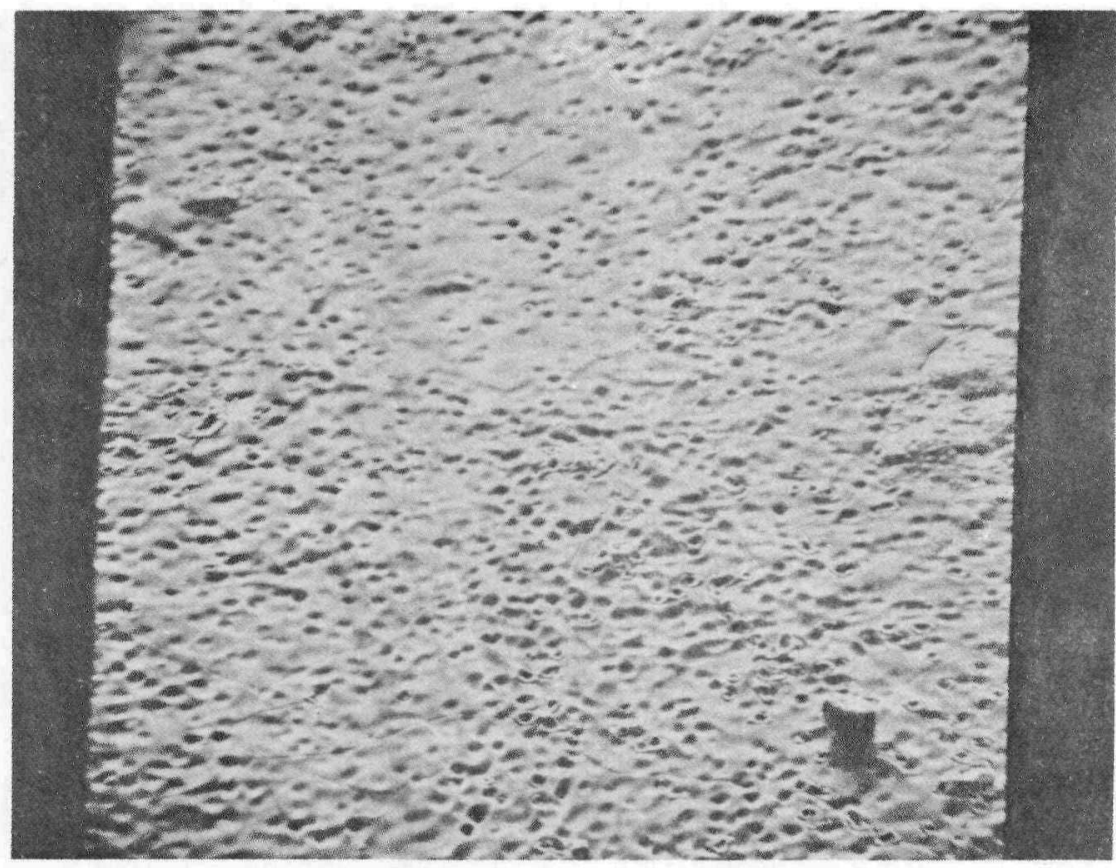

Molybdenum Sample D

After Coating with 25,000\& $\mathrm{Al}_{2} \mathrm{O}_{3}$ - Magnification 500X

FIGURE 33 


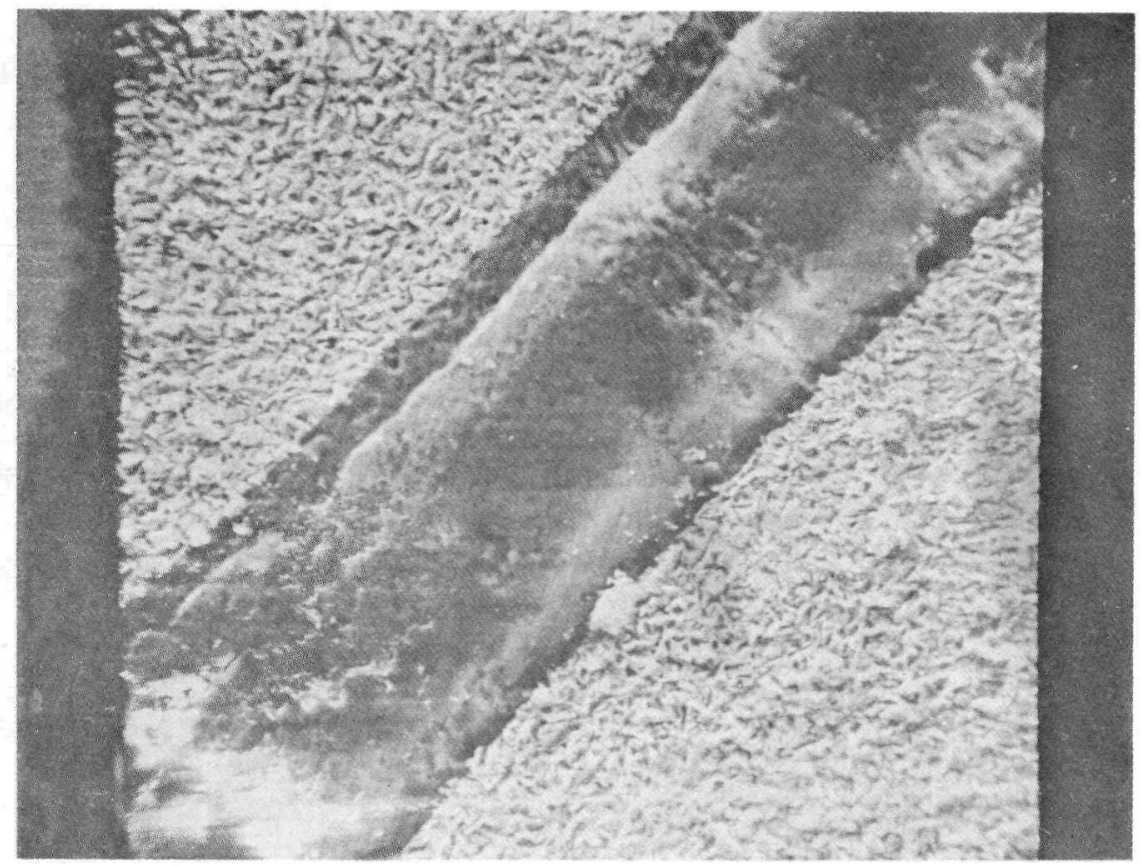

Photograph of Tri-Layer End-Area

Coated with 25,000 $\mathrm{Al}_{2} \mathrm{O}_{3}$ - Magnification 280X

FIGURE 34 
The development of the internally series connected module concept appears to be a feasible concept for obtaining an output voltage of approximately 28 volts. While the concept was not proven through the actual operation of the working model, successful development of the key module components, such as the integral emitter/collector tri-layer assembly and arc suppression coating, has shown the feasibility of the concept. The successful development of a lithium heat pipe for distribution of the input thermal power has also been shown. The concept design should be modified to gain further thermal stress relief in the collectorto-collector interconnection ring joint to permit E-B welding without risking the integrity of the arc suppression coating. The design might also be modified to permit a stepped approach of emitter to heat pipe assembly in order to eliminate the risk of molybdenum-to-molybdenum seizure during assembly. 


\section{APPENDIX A}

CONVERTER POWER LOSS ANALYSIS

Assuming

$$
\begin{array}{ll}
\mathrm{T}_{\mathrm{E}}=1450^{\circ} \mathrm{C} & \text { H.P. O.D. }-860 \\
\mathrm{~T}_{\mathrm{C}}=600^{\circ} \mathrm{C} & \text { H.P. I.D. }-750 \\
n=10 \% & \text { Wick I.D. }-720 \\
\mathrm{P}_{\mathrm{O}} / \text { conv. }=20 \text { watts } & \\
\mathrm{A}=5.5 \mathrm{~cm}^{2} &
\end{array}
$$

Power input $=\frac{20 \mathrm{w}}{n}=\begin{aligned} & 200 \mathrm{watts} / \mathrm{conv} \text { or } 47.79 \mathrm{Cal} / \mathrm{sec} \\ & \text { or }\end{aligned}$

Emitter tri-layer loss

$$
\begin{aligned}
& \Delta \mathrm{T}_{\mathrm{TRI}-E M}=\Delta \mathrm{T}_{2}+\Delta \mathrm{T}_{3}+\Delta \mathrm{T}_{4} \\
& \Delta \mathrm{T}_{4}=\frac{\mathrm{Qc} \ln \left(\mathrm{X}_{2} / \mathrm{X}_{1}\right)}{\mathrm{k} \mathrm{moly} 2 \pi \mathrm{I}} \\
& \Delta \mathrm{T}_{4}=\frac{(47.79)(.14105)}{(.21)(6.28)(.813)} \\
& \Delta \mathrm{T}_{4}=\frac{6.24^{\circ} \mathrm{C}}{\Delta \mathrm{T}_{3}=\frac{(47.79)(.010147)}{(.028)(6.28)(.813)}}
\end{aligned}
$$$$
\text { at } 1475^{\circ} \mathrm{C}
$$$$
\mathrm{k}_{\text {moly }}=.21 \mathrm{cal} / \mathrm{sec} / \mathrm{cm} /{ }^{\circ} \mathrm{C}
$$$$
\ln =\left(\frac{.570}{.495}\right)=.14105
$$

at $1475^{\circ} \mathrm{C}$

$\mathrm{k}_{\text {al203 }}=.028 \mathrm{cal} / \mathrm{sec} / \mathrm{cm} /{ }^{\circ} \mathrm{C}$ $\ln =\left(\frac{.495}{.490}\right)=.010147$

$$
\begin{aligned}
\Delta \mathrm{T}_{3} & =3.39^{\circ} \mathrm{C} \\
\Delta \mathrm{T}_{2} & =\frac{(47.79)(.13014)}{(.20)(6.28)(.813)}
\end{aligned}
$$

$$
\begin{aligned}
& \text { In }=\left(\frac{.490}{.430}\right)=.13014 \\
& \mathrm{k}=.20 \mathrm{cal} / \mathrm{sec} / \mathrm{cm} /{ }^{\circ} \mathrm{C} \\
& \text { moly at } \approx 1480^{\circ} \mathrm{C}
\end{aligned}
$$

$$
\begin{aligned}
& \Delta \mathrm{T}_{2}=6.09^{\circ} \mathrm{C} \\
& \Delta T_{T R I-E M}=6.09+3.39+6.24 \\
& =15 \cdot 72^{\circ} \mathrm{C}
\end{aligned}
$$

$$
\Delta \mathrm{T}_{5} \cong 1450^{\circ} \mathrm{C}-600^{\circ} \mathrm{C} \cong 850^{\circ} \mathrm{C}
$$


COLLECTOR TRI LAYER LOSS

$$
\begin{aligned}
& \Delta \mathrm{T}_{\mathrm{TRI}-\mathrm{COL}}=\Delta \mathrm{T}_{6}+\Delta \mathrm{T}_{7}+\Delta \mathrm{T}_{8} \\
& \Delta \mathrm{T}_{6}=\frac{\mathrm{Qc} \ln \left(\mathrm{X}_{2} / \mathrm{X}_{1}\right)}{\mathrm{km} 2 \pi \mathrm{L}} \\
& \Delta \mathrm{T}_{6}=\frac{(47.79)(.1527)}{(.285)(6.28)(.813)} \\
& \ln \left(\frac{.670}{.575}\right)=.1527 \\
& \mathrm{k}_{\text {moly }} \text { at } 600^{\circ} \mathrm{C} \\
& =.285 \mathrm{cal} / \mathrm{sec} / \mathrm{cm} /{ }^{\circ} \mathrm{C} \\
& \Delta \mathrm{T}_{6}=\underline{5.015^{\circ} \mathrm{C}} \\
& \Delta \mathrm{T}_{7}=\frac{(47.79)(.0074)}{(.024)(6.28)(.813)} \\
& \Delta \mathrm{T}_{7}=2.89^{\circ} \mathrm{C} \\
& \Delta \mathrm{T}_{8}=\frac{(47.79)(.1446)}{(.285)(6.28)(.813)} \\
& \ln \left(\frac{.675}{.670}\right)=.0074 \\
& \mathrm{kal}_{2} \mathrm{O}_{3} \text { at } 600=.024 \\
& \ln \left(\frac{.780}{.675}\right)=.1446 \\
& k=.285 \\
& \Delta \mathrm{T}_{8}=4.746^{\circ} \mathrm{C} \\
& \Delta \mathrm{T}_{\mathrm{TRI}-\mathrm{COL}}=5.015+2.89+4.746=12.651^{\circ} \mathrm{C}
\end{aligned}
$$

HEAT PIPE LOSS

$$
\begin{aligned}
& \Delta \mathrm{T}_{\mathrm{HP}}=\Delta \mathrm{T}_{\text {wall }}+\Delta \mathrm{T}_{\text {wick }} \\
& \Delta \mathrm{T}_{\text {HPwall }}=\frac{(47.79)(.1355)}{(.2073)(6.28)(.813)}
\end{aligned}
$$$$
\ln \left(\frac{.430}{.375}\right)=.1355
$$$$
\mathrm{k}_{\mathrm{TZM}} \text { at } 1500^{\circ} \mathrm{C}
$$$$
=.2073 \mathrm{cal} / \mathrm{sec} / \mathrm{cm} /{ }^{\circ} \mathrm{C}
$$

$\Delta \mathrm{T}_{\text {HPwall }}=6.12^{\circ} \mathrm{C}$

$\Delta \mathrm{T}_{\text {HPwick }}=\frac{(47.79)(.0816)}{(.164)(6.28)(.813)}$

$\ln \left(\frac{.375}{.360}\right)=.0816$

$\mathrm{k}=.164$ moly screen

$\Delta \mathrm{T}_{\mathrm{HP}}=6.12+4.66=10.78^{\circ} \mathrm{C}$ 
THUS

TOTAL $\triangle T$ FROM INSIDE H.P. TO EMITTER

$$
\begin{aligned}
& \Delta \mathrm{T}_{\mathrm{T}}=\Delta \mathrm{T}_{\mathrm{HP}}+\Delta \mathrm{T}_{\mathrm{TRI}-\mathrm{EM}} \\
& \Delta \mathrm{T}_{\mathrm{T}}=10.78+15.72 \\
& \Delta \mathrm{T}_{\mathrm{T}}=26.50^{\circ} \mathrm{C}
\end{aligned}
$$

LOSS /CON VERTER $=Q_{C O N V}+Q_{C S}+Q_{R A D}$

$Q_{\text {CONV. }}=200$ watts

$Q_{\text {CO }}=10.52$ watts

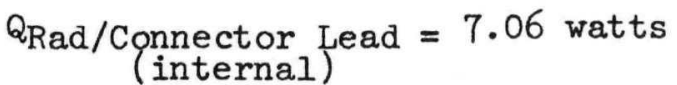

QTOTAL $=217.58$ watts $/$ converter cell

RADIATION LOSS FROM END LEAD

(LEAD TO HEAT PIPE SECTION)

$$
\begin{aligned}
& Q=\frac{A \sigma\left(T_{1}{ }^{4}-T_{2}{ }^{4}\right)}{\left(\frac{1}{e_{1}}+\frac{1}{e_{2}}-1+\frac{1}{e_{2}}+\frac{1}{e_{3}}-1\right)} \\
& Q_{E L}=27.1 \text { watts }
\end{aligned}
$$$$
\mathrm{e}_{1}=.42
$$$$
\mathrm{e}_{2}=.32
$$$$
\mathrm{e}_{3}=.12
$$$$
\AA=8.7 \mathrm{~cm}^{2}
$$

RADIATION LOSS, HEAT PIPE TO SHELL

$$
\begin{aligned}
\mathrm{e}_{1} & =.42 \\
\mathrm{e}_{2} & =.12 \\
\mathrm{~A} & =13.05 \mathrm{~cm}^{2}
\end{aligned}
$$

$$
\mathrm{Q}_{\mathrm{H}-\mathrm{S}}=62.6 \text { watts }
$$

RADIATION LOSS, END BELLOWS TO HEAT PIPE

$$
\begin{aligned}
\mathrm{e}_{1} & =.42 \\
\mathrm{e}_{2} & =.21 \\
\mathrm{~A} & =34.5 \mathrm{~cm}^{2}
\end{aligned}
$$

$Q_{E B-H P}=219.3$ watts 
END LEAD CONSTRUCTION

$$
\begin{array}{ll}
Q_{C L}=\frac{k A D T}{L} & L \cong 2.54 \mathrm{~cm} \\
& A=.3119 \mathrm{~cm}^{2} \\
& k=.32 @ 310^{\circ} \mathrm{C} \text { mean }
\end{array}
$$

$$
Q_{C L}=22.39 \text { watts }
$$

thus total Converter Power Loss for 10 Converter Module
A. 10 conv. $x Q_{T}=10 \times 217.58=2175$
B. END SLEEVES $=\left(Q_{E L}+Q_{H S}\right) 2=178$
C. END BELLOWS $=217 \times 2=434$
D. POWER IEAD $=2 \times 23=46$

TOTAL LOSS 2833 WATTS 
Respective Radii

$\begin{array}{ll}A=0.430 \mathrm{in} ., & 1.092 \mathrm{~cm} \\ \mathrm{~B}=0.490 & , 1.245 \\ \mathrm{C}=0.495 & , 1.257 \\ \mathrm{D}=0.570 & , 1.448 \\ \mathrm{E}=0.575 & , 1.460 \\ \mathrm{~F}=0.670 & , 1.702 \\ \mathrm{G}=0.675 & , 1.715 \\ \mathrm{H}=0.780 & , 1.981 \\ \mathrm{~J}=0.517 & , 1.313 \\ \mathrm{~K}=0.320 & , 0.813 \\ \mathrm{~L}=0.197 & , 0.50\end{array}$

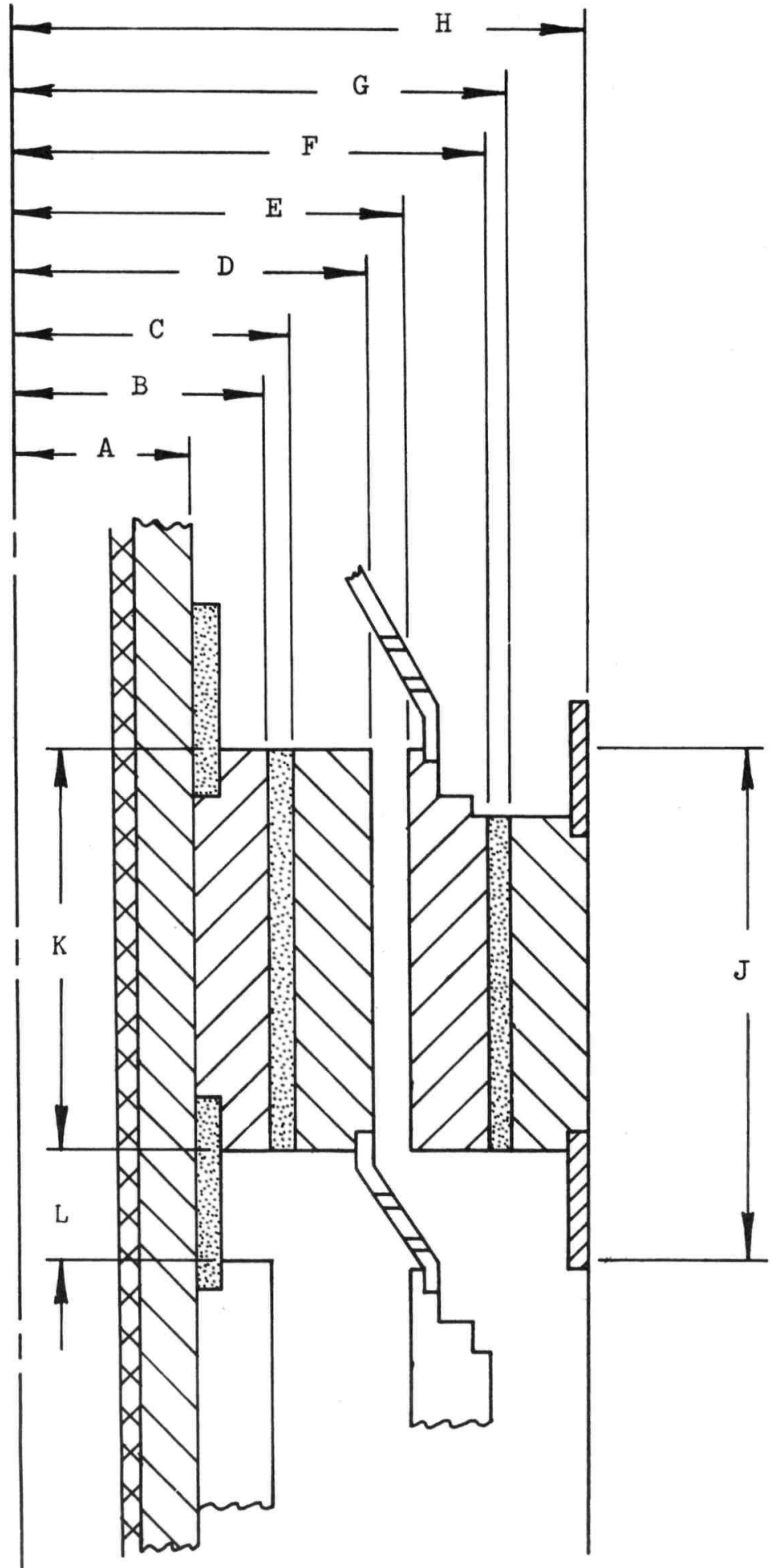

10 Converter Module Power Loss/Converter 